\title{
Repeat-mediated genetic and epigenetic changes at the FMR1 locus in the Fragile X-related disorders
}

\author{
Karen Usdin*, Bruce E. Hayward, Daman Kumari, Rachel A. Lokanga, Nicholas Sciascia and \\ Xiao-Nan Zhao
}

Section on Gene Structure and Disease, Laboratory of Cell and Molecular Biology, National Institute of Diabetes, Digestive and Kidney Diseases, National Institutes of Health, Bethesda, MD, USA

\section{Edited by:}

Lisa M. Pastore, University of Virginia, USA

\section{Reviewed by:}

Gary Latham, Asuragen, Inc., USA

Frank Kooy, University of Antwerp,

Belgium

\section{${ }^{*}$ Correspondence:}

Karen Usdin, Section on Gene

Structure and Disease, Laboratory of Cell and Molecular Biology, National Institute of Diabetes, Digestive and Kidney Diseases, Building 8, Room 2A19, National Institutes of Health, 8 Center Drive, MSC 0830, Bethesda, MD 20892-0830, USA

e-mail: ku@helix.nih.gov
The Fragile X-related disorders are a group of genetic conditions that include the neurodegenerative disorder, Fragile X-associated tremor/ataxia syndrome (FXTAS), the fertility disorder, Fragile X-associated primary ovarian insufficiency (FXPOI) and the intellectual disability, Fragile $X$ syndrome (FXS). The pathology in all these diseases is related to the number of CGG/CCG-repeats in the $5^{\prime}$ UTR of the Fragile $X$ mental retardation 1 (FMR1) gene. The repeats are prone to continuous expansion and the increase in repeat number has paradoxical effects on gene expression increasing transcription on mid-sized alleles and decreasing it on longer ones. In some cases the repeats can simultaneously both increase FMR1 mRNA production and decrease the levels of the FMR1 gene product, Fragile $X$ mental retardation 1 protein (FMRP). Since FXTAS and FXPOI result from the deleterious consequences of the expression of elevated levels of FMR1 mRNA and FXS is caused by an FMRP deficiency, the clinical picture is turning out to be more complex than once appreciated. Added complications result from the fact that increasing repeat numbers make the alleles somatically unstable. Thus many individuals have a complex mixture of different sized alleles in different cells. Furthermore, it has become apparent that the eponymous fragile site, once thought to be no more than a useful diagnostic criterion, may have clinical consequences for females who inherit chromosomes that express this site. This review will cover what is currently known about the mechanisms responsible for repeat instability, for the repeat-mediated epigenetic changes that affect expression of the FMR1 gene, and for chromosome fragility. It will also touch on what current and future options are for ameliorating some of these effects.

Keywords: Fragile X-related disorders, FX-associated tremor/ataxia syndrome (FXTAS), FX-associated primary ovarian insufficiency (FXPOI), Fragile X syndrome (FXS), repeat expansion disease

\section{INTRODUCTION}

The Fragile X-related disorders (FXDs) are members of a large and growing group of human genetic conditions known as the repeat expansion diseases (Fry and Usdin, 2006). These diseases all have an unusual mutational mechanism: the causative lesion is an increase in the number of repeats ("expansion") at a specific tandem repeat tract. In the case of the FXDs, the repeat unit is CGG/CCG and the repeat tract is located on the long arm of the X chromosome in the $5^{\prime}$ untranslated region of the Fragile X mental retardation 1 (FMR1) gene (Fu et al., 1991; Verkerk et al., 1991). This gene encodes Fragile X mental retardation 1 protein (FMRP), a protein important for learning and memory. Increasing repeat number is associated with increased instability of the repeat tract (Ashley-Koch et al., 1998; Nolin et al., 2011). The repeat number also has bearing on the severity of the FXD symptoms although, as will be described in more detail later, the relationship between repeat number and pathology is not always linear.

Alleles with $<45$ repeats are considered to be clinically unaffected and to have a very low risk of expansion, while alleles with $>54$ repeats confer risk of one or more of the FXDs as well as some risk of further expansion. Two pathological allele size classes are usually distinguished: alleles with 55-200 repeats are considered to be premutation (PM) alleles, while alleles with $>200$ repeats are referred to as full mutation (FM) alleles. PM alleles confer risk of an adult-onset neurodegenerative disorder known as Fragile X-associated tremor/ataxia syndrome (FXTAS) and/or a form of ovarian dysfunction known as Fragile X-associated primary ovarian insufficiency (FXPOI). In contrast, FM alleles are associated with Fragile X syndrome (FXS), the leading heritable cause of intellectual disability (Fu et al., 1991; Verkerk et al., 1991).

This review will briefly summarize some of the clinical features of the FXDs (the reader is referred to much more comprehensive discussions of this topic elsewhere in this issue) and then discuss current thinking about the underlying expansion mutation responsible for these diseases along with two specific consequences of this expansion, the chromosome fragility that gives these disorders their name and the repeat-mediated epigenetic changes that contribute to disease pathology.

\section{FRAGILE X-ASSOCIATED TREMOR/ATAXIA SYNDROME}

Fragile $\mathrm{X}$-associated tremor/ataxia syndrome is an adult onset neurodegenerative disorder whose symptoms include cerebellar ataxia and intention tremor [reviewed in (Hagerman, 2013)]. Cognitive decline or impairment, peripheral neuropathy, Parkinsonism, 
and urinary and bowel incontinence may also be seen. Magnetic resonance imaging (MRI) findings include global brain atrophy, enlarged ventricles, white matter disease, and increased signals in the middle cerebellar peduncle. In addition, characteristic intranuclear inclusions are seen in the brains and other organs of affected individuals. These inclusions are tau- and synuclein negative but contain FMR1 mRNA (Tassone et al., 2004) and a wide variety of other proteins (Iwahashi et al., 2006; Sellier et al., 2013). In general the severity of the FXTAS symptoms are directly related to the length of the CGG/CCG -repeat tract (Leehey et al., 2008) and there is a similar relationship between repeat number and the extent of FMR1 transcription in the PM range (Kenneson et al., 2001). However, the clinical symptoms and rate of progression of FXTAS vary and a life expectancy of anywhere between 5 and 25 years after the onset of symptoms is seen (Seritan et al., 2008). Males tend to be more severely affected than females, due at least in part to the protective effect of the second X chromosome in females (Berry-Kravis et al., 2005; Jacquemont, 2005; Coffey et al., 2008; Rodriguez-Revenga et al., 2009; Tassone and Hagerman, 2012).

\section{FRAGILE X PRIMARY OVARIAN INSUFFICIENCY}

Fragile X-associated primary ovarian insufficiency is an ovarian dysfunction disorder that presents with a spectrum of involvement ranging from heavy bleeding, irregular periods or increased rates of twinning, to infertility and menopause before the age of 40 (Sherman, 2000; Allen et al., 2007; Wittenberger et al., 2007). FXPOI is seen in $\sim 20 \%$ of females carrying a PM allele (Sullivan et al., 2011) and the PM is the leading cause of early menopause in the general population (Murray et al., 2014). Even women who carry the PM but do not meet the strict definition of FXPOI, tend to reach menopause on average 5 years earlier than their sisters without the PM (Murray et al., 2000, 2014; Sullivan et al., 2005). Women with FXPOI show signs of early ovarian aging including shorter than normal menstrual cycles than women who are still cycling, increased twinning, reduced levels of anti-müllerian hormone $(\mathrm{AMH})$ indicating a reduced follicle pool, and elevated follicle stimulating hormone (FSH; Welt et al., 2004; Rohr et al., 2008). The risk of FXPOI shows an unusual U-shaped relationship with repeat number with the highest risk being associated with alleles that have 80-99 repeats (Ennis et al., 2006; Allen et al., 2007; Tejada et al., 2008).

\section{FRAGILE X SYNDROME}

Fragile $\mathrm{x}$ syndrome is the most common heritable cause of intellectual disability and the most common known monogenic cause of autism [reviewed in (McLennan et al., 2011)]. It is associated with a wide range of symptoms of varying severity that may include speech and language delay, macroorchidism in males, hyperarousal and depression. Most males and 25\% of females have cognitive impairment (IQ $<70)$, while nearly all patients present with behavior problems, males typically with attention deficit hyperactivity disorder (ADHD) and aggression and females with shyness and social withdrawal (Hagerman and Hagerman, 2008). As many as $67 \%$ of male FM carriers meet the criteria for autism or autism spectrum disorder (ASD; Clifford et al., 2007; Wang et al., 2010). Seizures are seen in 10-20\% of affected children (Berry-Kravis, 2002). In $\sim 10 \%$ of children there is also a so-called
Prader-Willi phenotype that includes severe obesity, hyperphagia and hypogonadism or delayed puberty (Nowicki et al., 2007). At the cellular level, FXS is associated with immature dendritic spine morphology (Braun and Segal, 2000; Irwin et al., 2000). Amongst the effects seen at the molecular level there is dysregulated protein synthesis in the postsynaptic density in response to activation of the mGluR5 receptor that results in a net increased excitability of neuronal circuits (Bear et al., 2004; Dolen and Bear, 2008).

The FM allele is also associated with the expression of a folatesensitive fragile site for which the FXDs are named. This site appears as a gap, constriction or break that is seen in metaphase chromosomes when cells are subjected to folate-stress. In addition to this chromosomal abnormality, a number of female FM carriers have been shown to be mosaic for Turner syndrome (TS), a disorder in which one of the two X chromosomes has been lost (Shapiro et al., 1994; Tejada et al., 1994; Wilkin et al., 2000). The symptoms of TS include short stature, scoliosis, gonadal dysfunction, and cognitive problems including difficulties with spatial-temporal processing. Analysis of fetuses with the FM suggests that the risk of TS is significantly higher in female FM carriers than it is in the general population (Dobkin et al., 2009). Furthermore, unlike TS in the general population where the paternal X chromosome is more likely to be lost (Pelotti et al., 2003), in FX-related TS, it is the maternally transmitted chromosome carrying the FM allele (Dobkin et al., 2009).

\section{FXS IS A LOSS-OF-FUNCTION DISORDER WHILE FXTAS AND FXPOI ARE GAIN-OF-FUNCTION DISORDERS}

Individuals carrying intragenic loss of function mutations in the FMR1 gene show symptoms very similar to those carrying repeat expansions in the FM range (De Boulle et al., 1993; Gu et al., 1994; Lugenbeel et al., 1995; Myrick et al., 2014) and the disruption of the FMR1 gene in mice leads to the recapitulation of some aspects of FXS pathology including the increased density of immature dendritic spines (Comery et al., 1997). These data support the idea that FXS results from a failure to produce functional FMRP (Pieretti et al., 1991; Sutcliffe et al., 1992).

Since individuals with FXTAS and FXPOI make more FMRP than FM carriers who do not show signs of neurodegeneration or ovarian dysfunction, the symptoms of these disorders are thought to result from a gain of function of the transcript containing a large CGG-repeat tract. This gain of function may be related to the ability of transcripts containing the repeats to sequester CGG-repeat binding proteins, such as Sam68 (Sellier et al., 2010), DROSHA and DCR8 (Sellier et al., 2013) and Pur-alpha (Jin et al., 2007) and thus prevent their normal function, or to the fact that the repeats facilitate the generation or stabilization of a toxic protein that results from translation of the FMR1 transcript that is initiated at non-ATG codons (Todd et al., 2013).

\section{THE CLINICAL PRESENTATION OF THE FXDs CAN BE VERY VARIABLE}

A wide range of symptoms is seen in all three disorders and both FXTAS and FXPOI are incompletely penetrant (Jacquemont et al., 2004; Sullivan et al., 2005; Ennis etal., 2006; Allen et al., 2007; Tejada et al., 2008; Hagerman, 2013). In the case of FM carriers, a number of individuals do not meet the criteria for FXS having only mild symptoms reminiscent of FXS and an IQ within or close 
to the normal range (Hagerman et al., 1994; Wohrle et al., 1998; Taylor et al., 1999; Tassone et al., 2000b; Loesch et al., 2004, 2012; Tabolacci et al., 2008a; Santa Maria et al., 2013).

Furthermore, it is becoming apparent that there is some overlap in the clinical symptoms in PM and FM carriers. For example, small intranuclear inclusions characteristic of FXTAS have been reported in males with FM alleles who still make some FMR1 mRNA and some FM carriers have symptoms and MRI findings characteristic of FXTAS (Loesch et al., 2012; Santa Maria et al., 2013). Conversely, symptoms of ADHD, seizures, shyness, social deficits, ASD and occasionally intellectual disability that are more typical of FXS are also sometimes seen in PM carriers (Hagerman etal., 1996; Farzin etal., 2006; Grigsby et al., 2006, 2007; Hessl et al., 2007; Chonchaiya et al., 2012; Kim et al., 2014). In addition, increased FMR1 transcription and/or FXTAS symptoms have also been in reported in some carriers of FMR 1 alleles that have 45-54 repeats, so-called gray zone alleles (Kenneson et al., 2001; Hall et al., 2011, 2012; Liu et al., 2013). These alleles have also been suggested to contribute to the etiology of disorders associated with parkinsonism (Loesch et al., 2007, 2009; Hall et al., 2011; Trost et al., 2013). Some reports have also linked these alleles to ovarian dysfunction (Bretherick et al., 2005; Bodega et al., 2006; Streuli et al., 2009; Ishizuka et al., 2011; Karimov et al., 2011; Pastore et al., 2012; Barasoain et al., 2013) although others have found no such association (Bennett et al., 2010; Voorhuis et al., 2013; Murray et al., 2014).

\section{REPEAT INSTABILITY AT THE FX LOCUS}

The PM repeat tract is at risk of expansion on intergenerational transmission in humans. There is also some evidence of expansions occurring in some somatic tissues including the brain (Lokanga et al., 2013). Both small and large expansions are seen. Small expansions, which are seen more frequently on paternal transmission, give rise to larger PM alleles that affect the risk of FXTAS and FXPOI. The resultant larger alleles are also at increased risk of further expansions (Heitz et al., 1992). Large expansions give rise to FM alleles and these are exclusively maternally transmitted (Rousseau et al., 1991; Nolin et al., 1996; Ashley-Koch et al., 1998). In the gametes of male fetuses with FMs only FM alleles are observed (Malter et al., 1997), yet post-natally most FM males only have PM-sized alleles in their sperm (Reyniers et al., 1993; Rousseau et al., 1994). This would be consistent with the idea that expansions can occur in both males and females but that there is selection against large expansions during spermatogenesis. While expansions predominate, contractions are also seen including reversions of PM alleles into the normal size range (Mornet et al., 1996; Vaisanen et al., 1996; Gasteiger et al., 2003; Tabolacci et al., 2008b) and FMs into the PM range (Malzac et al., 1996; Loesch et al., 1997). It is some combination of these expansions and contractions that accounts for the repeat length mosaicism that is often seen in PM and FM carriers (Rousseau et al., 1991; Nolin et al., 1994; Prior et al., 1995; Cohen et al., 1996; de Graaff et al., 1996; Dobkin et al., 1996; Maddalena et al., 1996; Mila et al., 1996; Grasso et al., 1999; Petek et al., 1999; Schmucker and Seidel, 1999; Garcia Arocena et al., 2000; Fan et al., 2005; Govaerts et al., 2007; Todorov et al., 2009; Ferreira et al., 2013; Pretto et al., 2013; Santa Maria et al., 2013).
The mechanism of repeat instability is not fully understood. Both strands of the FX repeats are able to form a variety of intrastrand folded structures including hairpins and quadruplexes containing a mixture of Watson-Crick and Hoogsteen base interactions (Fry and Loeb, 1994; Mitas et al., 1995; Nadel et al., 1995; Usdin and Woodford, 1995; Usdin, 1998; Fojtik and Vorlickova, 2001; Renciuk et al., 2009). The ability to form such structures is a common feature of those diseases arising from repeat expansion (reviewed in Usdin, 2008). This has led to the suggestion that expansion arises from a problem related to the formation of these structures. In addition to gender, two key factors have been identified that affect expansion risk in humans. These are the length of the repeat tract and the presence or absence of AGG-interruptions within the tract (Eichler etal., 1994; Zhong etal., 1996; Kunst et al., 1997; Nolin et al., 2003, 2011, 2013; Yrigollen et al., 2012). In vitro studies show that the presence of an AGG-repeat interruption diminishes the stability of the secondary structures formed by a CGG-repeat tract (Weisman-Shomer et al., 2000; Jarem et al., 2010). Thus the fact that AGG-interruptions reduce instability would be consistent with a role of these structures in repeat expansion.

Repeat instability has been studied in a number of mouse models of the PM (Bontekoe et al., 1997; Lavedan et al., 1998; Peier and Nelson, 2002; Fleming et al., 2003; Entezam et al., 2007; Brouwer et al., 2008). While small expansions are seen at a high frequency in mouse models with $\sim 130$ repeats, the large expansions characteristic of the generation of a FM allele in humans are only rarely seen in these animals. However, longitudinal studies of the size of the transmitted allele in mice also demonstrates that alleles can undergo multiple rounds of expansion over time, with the changes in the repeat number in the transmitted allele increasing with increasing repeat number (Lokanga et al., 2013; Zhao and Usdin, 2014). This raises the possibility that the large expansions seen in humans may arise from the accumulated effect of a series of small expansions. Since the perigametic interval, the time between the last premeiotic cell division in the gamete of the parent and the first mitotic division in the offspring, usually lasts two decades or more in humans compared to a few weeks or months in rodents, humans have a much larger window of opportunity during which repeat units can be added. The incremental accumulation of additional repeats with time may also account for the observed parental age effect on the risk of expansion seen in humans (Ashley-Koch et al., 1998). In addition, PM alleles with 190 repeats show much larger expansions than PM alleles that only have 130 repeats, raising the possibility that the threshold for large expansions is higher in mice than it is in humans (Entezam et al., 2007).

\section{MODELS FOR REPEAT EXPANSION}

There are a number of different models for repeat expansion, some of which are based on the idea that expansion results from some problem associated with DNA synthesis through the repeats during normal genomic replication and others that suggest that expansion occurs as a result of aberrant repair of the secondary structures formed by the repeats perhaps during transcription or as a result of DNA damage (see Pearson et al., 2005; Mirkin, 2007 for comprehensive reviews). One of these models, the ORI-switch model, proposes that expansion occurs during normal genome 
replication as the result of a switch or change in the origin of replication (ORI) used to replicate the locus in question. This switch results in a change in the direction of replication through the repeat (Mirkin and Smirnova, 2002). This switch could potentially occur in the embryo when cell division is very rapid and additional ORIs are needed to complete replication timeously. This model is predicated on the premise that expansions and contractions occur via strand-slippage during replication, a process more likely to occur during lagging strand DNA synthesis. The most stable secondary structure is thought to be the one most likely to promote slippage since it would favor repriming of DNA synthesis from the slipped position. Since the secondary structures formed by the CGGrepeats are more stable than those formed by the CCG-repeats, this model would predict that replication from an upstream ORI, that results in the CGG-repeats being on the lagging strand template, would favor contractions since repriming by the nascent strand after strand-slippage would likely occur $5^{\prime}$ of the structure on the template as illustrated in Figure 1A. In contrast, replication from a downstream ORI would result in the CGG-repeats being on the nascent Okazaki fragment and would thus favor expansions since repriming by the nascent strand further $3^{\prime}$ on the template would occur more often.

In normal human embryonic stem cells (ESCs) and in differentiated cells with either normal or FX alleles, replication proceeds equally well from ORIs located $>45 \mathrm{~kb}$ upstream and downstream of the repeat (Gerhardt et al., 2014). However, in FX ESCs replication proceeds predominantly from the downstream ORI such that the CGG-strand would be on the Okazaki fragment consistent with the requirements of the ORI-switch model (Gerhardt et al., 2014). Since in somatic cells replication through the FMR1 locus proceeds from both origins, the prediction of the model would be that both expansions and contractions can occur with equal probability resulting in no net gain of repeats. In contrast, since in FX ESCs replication proceeds predominantly from the downstream ORI, expansions would predominate in these cells. However, since the change in ORI usage seen in FX ESCs does not occur in normal ESCs, the switch in ORI site usage is not an intrinsic feature of the FMR1 locus in this cell type. This raises the question of what causes the ORI-switch in FX cells in the first place. Further work is needed to understand whether the change in ORI usage in FX ESCs is a consequence of the expansion event that gave rise to the FX allele or the cause. Since the FMR1 gene is already methylated in the FX ESCs studied, it would be useful to examine ESCs from individuals with unmethylated FM alleles to assess the role of DNA methylation in ORI switching.

While it is possible that problems at the replication fork are responsible for expansion, there are a number of lines of evidence that support other types of models. For example, expansion is known to be high in tissues with a low proliferative capacity like brain and liver and in a mouse model of the FX PM expansion is seen in post-mitotic cells such as oocytes and neurons (Lokanga et al., 2013). This, along with data emerging from other repeat expansion diseases, suggests that genomic replication may not be required for expansion (Lia et al., 1998; Fortune et al., 2000; Ishiguro et al., 2001; Kovtun and McMurray, 2001; Lokanga et al., 2013, 2014b). Furthermore, oxidative damage has been shown to be risk factor for expansion in a PM mouse model (Entezam et al., 2010), supporting the idea that an aberrant DNA damage response rather than a problem with replication may be responsible for expansion. This idea is bolstered by the finding that mutations in the genes for OGG1 and NEIL1, two DNA glycosylases involved in base excision repair (BER) of oxidized bases, decrease the expansion frequency in a mouse model of Huntington Disease, a Repeat Expansion Disorder involving CAG-repeats (Kovtun et al., 2007; Mollersen et al., 2012).

The mismatch repair (MMR) protein MSH2 has been shown to be essential for both intergenerational and germ line expansions in the FX PM mouse (Lokanga et al., 2014b). MSH2 has also been implicated in expansion in mouse models of other Repeat Expansion Diseases (Manley et al., 1999; Savouret et al., 2003). In addition to providing clues as to the mechanism of expansion, the effect of parental Msh2-heterogosity in the FX PM mouse also tells us something about the timing of these expansions. Specifically, the $M s h 2^{-/-}$offspring of $M s h 2^{+/-}$parents have the same expansion frequency as their $M s h 2^{+/+}$and $M s h 2^{+/-}$ littermates. Thus, expansion events detected at birth are predominantly the result of expansion events occurring prezygotically. This may be pertinent to the question of whether expansions seen on intergenerational transmission in humans occur prezygotically or postzygotically (Moutou et al., 1997; Reyniers et al., 1999; Huang et al., 2014).

MSH2 likely binds the FX DNA hairpins as part of the MutS $\beta$ complex, as reported for the hairpins formed by CAG/CTGrepeats (Owen et al., 2005; Lang et al., 2011). MutS $\beta$, a heterodimer of MSH2 and MSH3, normally binds and triggers the repair of insertion-deletion (IDL) loops of 1-15 nucleotides. The FX repeats form hairpins with $\mathrm{G} \bullet \mathrm{G}$ and C•C mismatches (Mitas et al., 1995; Usdin and Woodford, 1995; Yu et al., 1997; Usdin, 1998) and it is likely that binding to the FX repeats occurs via the recognition of these mismatched bases. However, whether MSH2 is acting via classical MMR to recruit other MMR proteins or via another DNA repair pathway, like BER, in which $\mathrm{MSH} 2$ also participates, is currently unclear.

While expansion in the mouse model does not seem to require genomic replication, it does require transcriptionally competent chromatin since expansion only occurs when the PM allele is situated on the active X chromosome (Lokanga et al., 2014a) This is consistent with observations from humans, that methylated alleles that are transcriptionally inactive, are stable (Wohrle et al., 2001). Loss of Cockayne syndrome B (CSB), a protein essential for transcription coupled repair (TCR), a DNA repair pathway that is unique to actively transcribed genes, affects germ line, and somatic expansion risk in the PM mouse (Zhao and Usdin, 2014). It also causes a decrease in the extent of somatic expansion in some organs but not others indicating that CSB facilitates, but is not essential for expansion. Since TCR requires CSB, its non-essential role suggests that the expansion process does not involve TCR itself. It may be that CSB is acting via its ability to facilitate steps in the BER pathway (Muftuoglu et al., 2009; Menoni et al., 2012; Aamann et al., 2013).

Since TCR is not essential for somatic expansions, the fact that expansion only occurs on the active $\mathrm{X}$ chromosome must have a different molecular basis. It may simply be that occlusion 


\section{A}

\section{ORI-switching model for repeat instability}

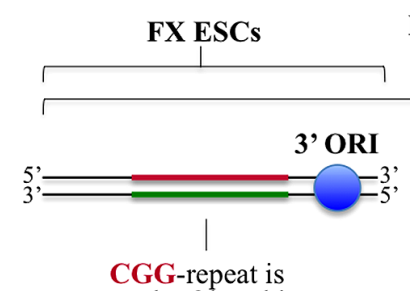

on the Okazaki

fragment

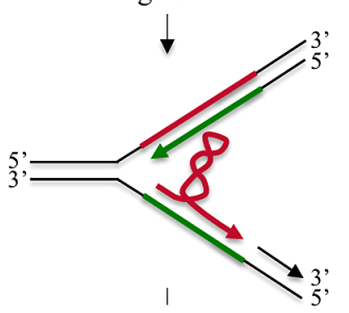

Strand slippage

and repriming

further

upstream on

the template

expansion
Normal ESCs and both FX

and normal somatic cells

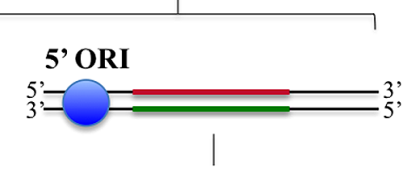

CGG-repeat is on the lagging strand template

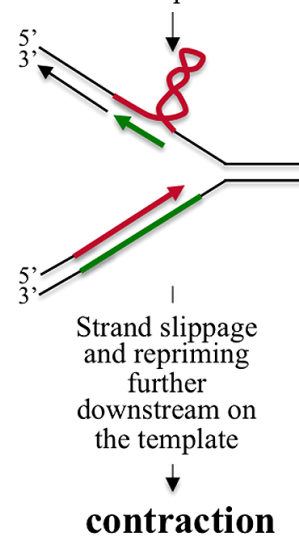

B

\section{DNA damage repair model for repeat instability}

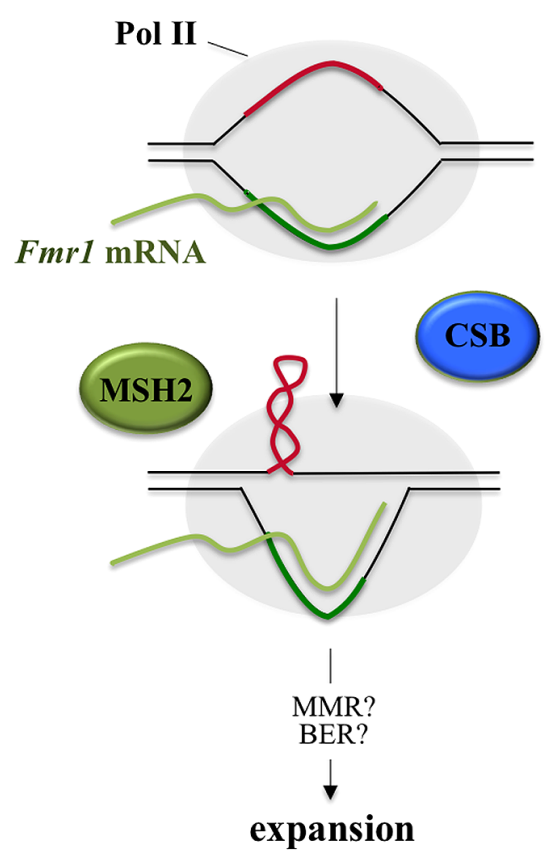

FIGURE 1 | Models for intergenerational repeat instability at the FX locus. In both models the CGG-rich strand, which forms the most stable secondary structure, is shown in red and the CCG-rich strand is shown in green. (A) ORI-switch model for FX repeat instability. The FMR1 gene is flanked by two ORIs, one located $45 \mathrm{~kb}$ upstream $\left(5^{\prime}\right)$ and another $45 \mathrm{~kb}$ downstream $\left(3^{\prime}\right)$ of the gene (Gerhardt et al., 2014). During replication transient dissociation of the Watson and Crick strands of DNA can occur with slippage of the two strands relative to one another. Priming of DNA synthesis can then occur from the slipped position. This strand-slippage process is thought to occur more commonly during lagging strand replication and is seen more frequently when the template or nascent strand have the potential to form secondary structures. Secondary structure formation by the lagging strand template would result in loss of repeats/contractions since repriming $5^{\prime}$ of the structure on the template would be favored, while the formation of such structures on the corresponding Okazaki fragment would favor addition of repeats since repriming would then be more likely to occur more $3^{\prime}$ on the template. Replication from the upstream ORI results in the CGG-rich strand being on the lagging strand template (note that only one side of the bidirectional replication fork is shown). In contrast, replication from the downstream ORI results in the CGG-rich strand being on the Okazaki fragment. In somatic cells replication proceeds equally well from both ORIs resulting in no net gain of repeats. However, in FX ESCs it is suggested that replication predominantly occurs from the downstream ORI resulting in a net gain of repeats. (B) A DNA repair based model for FX repeat instability. During transcription, RNA Polymerase II (Pol II) occludes the template strand, leaving the non-template strand free to form secondary structures. Secondary structure formation may also be facilitated by the co-transcriptional formation of stable RNA:DNA hybrid in the repeat region (Loomis etal., 2014). These structures are then processed via an

MSH2-dependent expansion pathway in which CSB plays a supportive role. This pathway is initiated by binding of the MSH2-containing complex to the mismatches in the structures. Events downstream of this binding are not currently known. One possibility is that classical mismatch repair is initiated in response to $\mathrm{MSH} 2$ binding but that hairpins form in the flaps generated by strand displacement synthesis as part of this repair. Hairpin formation may prevent normal removal of these bases by flap endonucleases (Spiro etal., 1999) resulting in their incorporation into the "repaired" strand. of the template strand by the RNA polymerase II (Pol II) during transcription increases the opportunity for the formation of the secondary structures on the non-template strand that act as the substrates for expansion. Alternatively, the effect of transcription may be mediated via the formation of persistent RNA:DNA hybrids or R-loops at the FMR1 locus (Loomis et al., 2014). These R-loops may allow the expansion substrates to form because reannealing of the duplex behind Pol II cannot take place. These data suggest a model for repeat instability in which transcription results in the formation of the secondary structures that act as the substrate for the MSH2-dependent, CSB-facilitated expansion pathway as illustrated in Figure 1B.

\section{POTENTIAL APPROACHES TO REDUCING EXPANSION RISK}

While repeat length and purity seem to be the most important factors driving expansion of PM alleles in humans, it may be that other genetic or environmental factors contribute to expansion risk in smaller PM alleles or in gray zone/intermediate alleles. The fact that ATM protects the genome against repeat expansion in mice (Entezam and Usdin, 2008, 2009) is of interest in this regard since ATM mutations are relatively common in the human population (Swift et al., 1986) and may thus be a relatively common source of variability in the extent of expansion in carriers of smaller alleles. Our demonstration that oxidative stress increases expansion risk in mice is of general interest since there are many 
sources of oxidative stress to which both rodents and humans are exposed. These include internal sources, resulting from normal metabolism, and external sources in the form of environmental pollutants, ionizing and ultraviolet radiation, heat shock, and sources of inflammation. However, whether dietary antioxidants can protect against expansions is not known.

The contribution of the MSH2 binding partners MSH3 and MSH6 to repeat expansion in FX or the FX PM mice is not known. However, while MSH6 has been shown to be important for expansion in Friedreich ataxia (FRDA) induced pluripotent stem cells (Du et al., 2012), in mouse models of other repeat expansion diseases, it is MSH3 that is important (van den Broek et al., 2002; Foiry et al., 2006; Tome et al., 2013). It has been suggested that the development of MSH3 inhibitors may have therapeutic potential since loss of MSH3 is less deleterious than the loss of either MSH2 or MSH6 (Foiry et al., 2006; Halabi et al., 2012). Furthermore, the data suggest that improving the efficacy of the pathways that lead to contractions or error-free repair could in principle reduce expansion risk.

\section{REPEAT-MEDIATED EPIGENETIC EFFECTS}

Curiously, CGG-repeats can both enhance and repress FMR1 gene expression, causing hyperexpression of PM alleles and hypoexpression or silencing of FM alleles. The mechanisms involved are not at all well understood.

\section{HYPEREXPRESSION OF THE PM ALLELE}

Fragile X mental retardation $1 \mathrm{mRNA}$ is expressed at elevated levels in cells of humans (Tassone et al., 2000c) and mice with the PM allele (Entezam et al., 2007; Brouwer et al., 2008). These levels are directly related to repeat number and can be as high as 10 times that of the FMR1 transcript in normal cells. Since the pathology seen in PM carriers is thought to be related either to the ability of the RNA to sequester proteins or the toxic proteins that can be made from the PM transcripts, the elevated levels of PM mRNA is likely to contribute to disease severity. The increased RNA levels are the result of increased transcription initiation rather than increased transcript stability (Tassone et al., 2007). Thus the CGG-repeats may act as a downstream enhancer/modulator of transcription. The increase in mRNA is also correlated with changes in transcription start site usage in which larger PM alleles initiate transcription from upstream start sites more frequently than occurs in normal cells (Beilina et al., 2004). This is suggestive of an altered chromatin conformation on the PM allele.

The increase in FMR1 transcription in PM carriers is known to be associated with an increased abundance of acetylated histones at the FMR1 promoter (Todd et al., 2010), however, whether this is a cause or consequence of the increased transcription remains to be determined. Long tracts of CGG-repeats have been shown to exclude nucleosomes in vitro (Wang et al., 1996). Should this also occur in vivo it could potentially lead to increased transcription by increasing the accessibility of transcription factors to the promoter. The R-loops formed by the CGG-Repeats (Groh et al., 2014; Loomis et al., 2014) could also play a role in FMR1 hyperexpression. R-loops may be less prone to assemble nucleosomes (Dunn and Griffith, 1980) and more prone to chromatin decondensation (Powell et al., 2013). The effect of the longer Rloops formed on an expanded repeat may extend further into the flanking regions perhaps enhancing binding of the promoter by transcription factors or chromatin modifiers that in turn promote transcription initiation. It is also possible that the FX repeats directly bind factors that can remodel chromatin or regulate FMR1 transcription. For example, pur alpha and pur beta are multifunctional proteins that can bind CGG-repeats very effectively and in some contexts are known to activate transcription (Huang et al., 2009).

\section{REPEAT-MEDIATED GENE SILENCING OF FM ALLELES}

Most FM alleles are largely or completely silenced. How this silencing is accomplished is not well understood or how it is that some carriers of FM alleles escape this silencing. The $5^{\prime}$ end of the FMR1 gene in FXS-derived patient cell lines is hypermethylated and associated with hypoacetylated histones (Chiurazzi et al., 1998, 1999; Coffee et al., 1999; Pietrobono et al., 2002, 2005; Biacsi et al., 2008). In addition, histone H3 is hypomethylated on lysine 4 (H3K4) on FX alleles and enriched for dimethylated H3K9 and trimethylated $\mathrm{H} 3 \mathrm{~K} 27$, marks typical of developmentally regulated genes, as well as trimethylated $\mathrm{H} 3 \mathrm{~K} 9$ and trimethylated H4K20, marks typically seen on constitutive heterochromatin like the tandem repeats that make up the pericentric heterochromatin (Kumari and Usdin, 2010). However, when these modifications are deposited and the sequence of events involved is unclear.

A study of FMRP expression in chorionic villi (CV) of two male Fragile $\mathrm{X}$ fetuses led to the suggestion that silencing of the FX allele occurs in the CV between 10 and 12.5 weeks of age (Willemsen et al., 2002). However, in other studies DNA methylation of the FX allele was already detectable in CV samples of 8-10 week old fetuses (Devys et al., 1992). In general, reprogramming of DNA methylation is thought to occur earlier in the embryo than in trophectoderm-derived cell lineages (Santos et al., 2002). Whether FX gene methylation also occurs earlier in the embryo remains to be seen but would be consistent with the observation that 2 out of the 3 ESC lines that have been derived so far are already methylated (Colak et al., 2014; Gerhardt et al., 2014).

In a study of an unmethylated FX ESC line, teratomas derived from these ESCs showed a $\sim 20$-fold reduction in transcription along with enrichment for $\mathrm{H} 3 \mathrm{~K} 9$ methylation, while the DNA was still unmethylated (Eiges et al., 2007). This suggests DNA methylation is a relatively late event in the silencing process. Other evidence that supports this idea is the fact that carriers of unmethylated FM alleles (UFMs) show evidence of H3K9 dimethylation characteristic of silenced alleles but no DNA or H3K27 methylation (Tabolacci et al., 2008a). Furthermore, treatment of patient cells with the demethylating agent 5-azadeoxycytidine (AZA) reduces DNA methylation but does not affect the levels of H3K9 methylation (Chiurazzi et al., 1998, 1999; Coffee et al., 1999; Pietrobono et al., 2002, 2005; Biacsi et al., 2008). The idea that DNA methylation is a relatively late event in the silencing process would be consistent with the observation that de novo methylation of many other genes is associated with prior histone methylation (Feldman et al., 2006; Vire et al., 2006; Dong et al., 2008; Epsztejn-Litman et al., 2008; Tachibana et al., 2008). 
A contrasting picture of events emerges from a study of two other ESC lines. In these cells H3K9 dimethylation and loss of FMR1 transcription was only seen after $>45$ days of neuronal differentiation (Colak et al., 2014). However, the FM allele in these ESCs was already at least partially methylated as evidenced by the resistance of the promoter to Eag I digestion. Thus presumably early events in the silencing process had already taken place prior to neuronal differentiation. Nonetheless, these data suggest that in this system H3K9 dimethylation occurs many weeks after DNA methylation had begun, an observation that is perplexing given the normally close linkage between these events.

A key unresolved question in the field is what is the trigger for gene silencing. The distribution of histone modifications on the FX allele may provide some insight into where the target may be. For example, H3K9me3 and H4K20me3, marks typical of constitutive heterochromatin, show a peak of enrichment in the region of the repeat, while the other histone modifications are more uniformly distributed across the $5^{\prime}$ end of the gene. The enrichment of H3K9me3 and H4K20me3 would be consistent with the idea that the repeats themselves are the early target of the silencing process. Deposition of other histone marks more typical of developmentally regulated genes onto the FMR1 $5^{\prime}$ end may be a consequence of the loss of a proposed boundary element located between the FMR1 gene and the zone of heterochromatin found upstream of the FMR1 gene on normal and affected alleles (Kumari and Usdin, 2010). The nature of the boundary element is unclear but while CCCTC-binding factor (CTCF) binds to this region, this factor is unlikely to be involved (Lanni et al., 2013). It is also possible that the broader distribution of $\mathrm{H} 3 \mathrm{~K} 9 \mathrm{me} 2$ and $\mathrm{H} 3 \mathrm{~K} 27 \mathrm{me} 3$ reflects a greater ability of these heterochromatin marks to spread than the marks of constitutive heterochromatin. In either event, the data support the idea that the initiation of silencing begins in the repeat itself (Kumari and Usdin, 2010).

Models for the initiation of gene silencing fall into two basic groups, one in which the DNA itself recruits factors that ultimately result in the accumulation of repressive chromatin and the other in which RNA produced locally or distally in the form of short or long coding or non-coding RNAs is the trigger.

\section{DNA-based models for the nucleation of silencing}

The secondary structures formed by the repeats are known to be particularly good substrates for DNA methyltransferases in vitro (Smith et al., 1994). This has led to a model in which hairpin formation by the repeats in DNA triggers de novo DNA methylation as the first step in the silencing process as illustrated in the left hand panel of Figure 2A. However, if DNA methylation were in fact a later event in the silencing process, then this model would presumably not apply.

An alternate model for DNA-based initiation of silencing is seen in pericentromeric repeats in mice that occurs when the transcription factors Pax3 and Pax9 bind to the repeats and recruit the $\mathrm{H} 3 \mathrm{~K} 9$ trimethylase, Suv39h1 (Bulut-Karslioglu et al., 2012) as illustrated in the right hand panel of Figure 2A. The repeats that bind Pax3 and Pax9 are A+T-rich making it unlikely that the same factors bind to the FX repeats. However, it has been suggested that other repeat-binding proteins may act in the same way to bring about gene silencing (Bulut-Karslioglu et al., 2012).

\section{RNA-based models for the nucleation of silencing}

The FMR1 locus produces a complex mixture of sense and antisense transcripts that could potentially trigger gene silencing in a variety of other ways (Ladd etal., 2007; Kumari and Usdin, 2010; Pastori et al., 2014). The CGG-repeats in RNA can form hairpins that are substrates for the enzyme Dicer, an important component of the RNA interference (RNAi) pathway (Handa et al., 2003). In mammals this pathway is usually associated with the post-transcriptional regulation of $m R N A s$ but in fission yeast it can also lead to transcriptional gene silencing of centromeric repeats (Volpe et al., 2002). Dicer processes RNAs with doublestranded character into small interfering RNAs that, at least in yeast, are loaded onto the RNA-induced transcriptional silencing (RITS) complex. This complex can lead to gene silencing via the recruitment of Swi6/HP1 and a protein with similarities to the mammalian Suv39h protein (Nakayama et al., 2001; Rougemaille et al., 2012). Whether such a system operates in mammals is the subject of some debate. Work in human cells suggests that an analogous process does operate as illustrated in the right hand panel of Figure 2B (Kim et al., 2006). However, no evidence of abnormal methylation is seen at other CGG-repeat tracts in the human genome (Alisch et al., 2013). It is possible that the repeat number at any given locus has to exceed a certain threshold in order to be susceptible to silencing (Alisch et al., 2013). Such a threshold effect might also explain why the FM alleles are not silenced in mouse models for expanded repeats (Entezam et al., 2007; Brouwer et al., 2008). It is also possible that the silencing mechanism acts only in cis. Work done in neurons differentiated from FX ESCs suggested that Dicer is not required for either shutting down transcription of the FMR1 gene or for dimethylation of H3K9 (Colak et al., 2014). However, since these cells were already at least partially methylated before differentiation began, a role for Dicer in the earliest steps of the silencing process cannot be excluded.

A number of Dicer-independent RNA-mediated silencing mechanisms are also possible. One such mechanism is related to the reported ability of the CGG-repeats to form persistent RNA:DNA hybrids (R-loops; Colak et al., 2014; Groh et al., 2014; Loomis et al., 2014). An R-loop containing the repeat is seen at the FMR1 locus in neurons derived from FX ESCs. This R-loop appears after 45 days of differentiation and is followed by silencing of the FMR1 gene (Colak et al., 2014). In these experiments no R-loop was seen in normal ESCs or cells from patients with FXTAS. A small molecule that is thought to block R-loop formation prevents gene silencing supporting the idea that the R-loop is crucial for this process. However, since some DNA methylation is already apparent in the ESCs prior to differentiation, it is likely that other events in the silencing process precede the action of the RNA:DNA hybrid. Why the R-loop is only seen in this small window of time is unclear, particularly since they can be readily detected in differentiated dermal fibroblasts even on shorter alleles (Loomis et al., 2014). Furthermore, why so much time elapses between the initiation of DNA methylation and the other epigenetic modifications that lead to silencing is also perplexing. However, there are a number of ways that R-loops could trigger silencing of the FX allele. They may cause transcription termination directly as do the R-loops generated by the repeat 


\section{A}

DNA-mediated initiation of silencing

B

Hairpin-mediated

TF/binding protein-mediated
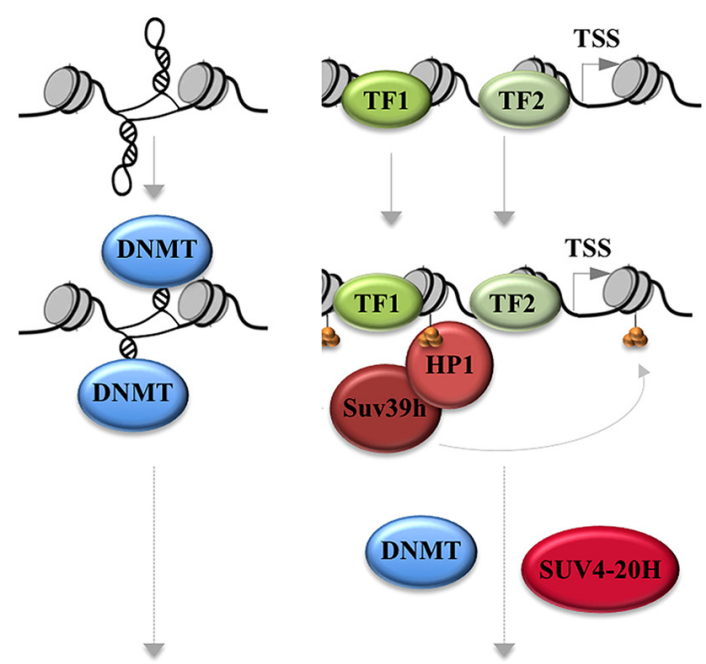

silenced allele H 13 K27me3 silenced allele $\$$ H3K9me 2

\section{RNA-mediated initiation of silencing}

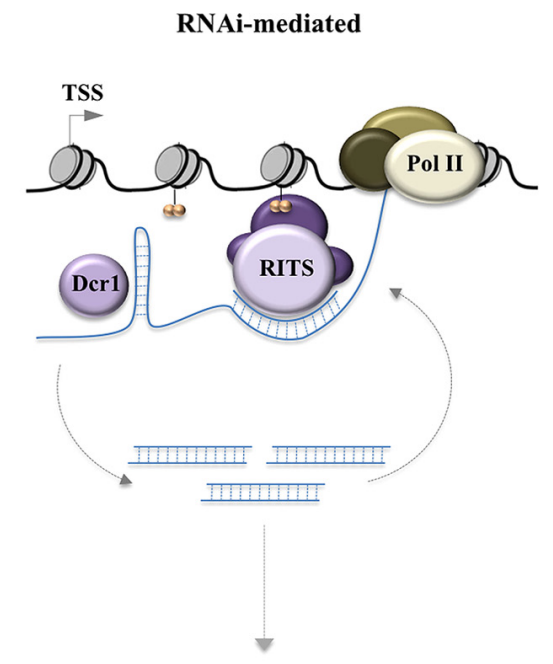

silenced allele
RNA:DNA hybrid-mediated

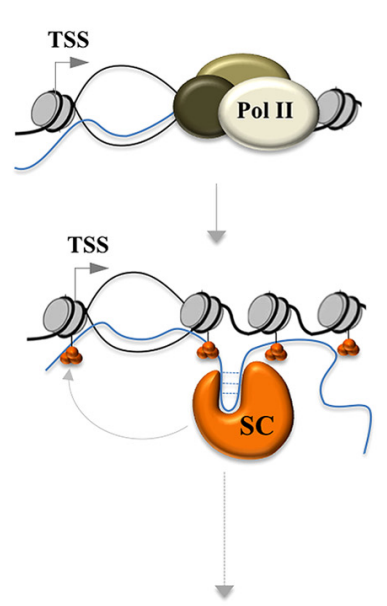

silenced allele

$$
\text { P H3K27me3 } \$ \text { H3K9me2 }
$$

FIGURE 2 | Models for FX gene silencing. Potential early steps in the initiation of FX gene silencing are depicted. (A) Two ways in which silencing can be triggered by the FX DNA. The left hand panel depicts a model based on the propensity of DNA methyltransferases to methylate FX hairpins in vitro (Smith etal., 1994; Chen etal., 1995). The right hand panel depicts a silencing scheme in which repeat binding proteins act to recruit silencing complexes based on the silencing mechanism that is thought to be responsible for the silencing of the major satellite repeats in pericentric heterochromatin in mice (Bulut-Karslioglu etal., 2012). In the case of the major satellite repeats recruitment of Suv39h leads to the recruitment of DNA methylases and SUV4-20H which trimethylates H4K20. DNMT: DNA methyltransferase; TF: transcription factor; TSS: transcription start site. (B) Two ways in which RNA-mediated gene silencing might occur in the FX locus. The left hand panel depicts an RNA interference based mechanism for gene silencing based on the model of silencing of centromeric tandem repeats in the fission yeast, Schizosaccharomyces pombe Nolpe et al., 2002). In the FX locus the RNA hairpins formed by the FX repeats in the FMR1 transcript may be the source of the double-stranded Dicer (Dcr) substrates (Handa etal., 2003) as illustrated. In this case the annealing of the small Dicer products to the FMR1 mRNA would occur via the same combination of Hoogsteen and Watson-Crick base pairing that generates the RNA hairpins in the first place. Alternatively, the duplex RNAs could be generated by base pairing of FMR1 mRNA with an antisense transcript generated from this region (Ladd etal., 2007). The RNA-induced transcriptional silencing (RITS) complex, which includes the argonaute family member AGO1, then could mediate heterochromatin formation by associating with nascent transcripts via base pairing with the Dcr products. AGO1 could then recruit other epigenetic modifiers including members of the Polycomb (PcG) Group Complexes including EZH2 as suggested by work in human cells (Kim etal., 2006). The right hand panel depicts a way in which an RNA:DNA hybrid may initiate silencing by tethering the FMR1 transcript to the FMR1 locus while also recruiting silencing complexes (SC) that bind to the repeat, perhaps to the secondary structures formed by the repeat, analogous to what has been reported for the RASSF1A locus (Beckedorff etal., 2013) and for ribosomal DNA repeats and IAP elements (Bierhoff etal., 2014). Dcr1: Dicer 1; Pol II: RNA Polymerase II; RITS: RNA interference (RNAi) effector complex; SC: silencing complex; TSS: transcription start site. that causes the Repeat Expansion Diseases, amyotrophic lateral sclerosis (ALS) and frontotemporal lobar degeneration (FLTD; Haeusler et al., 2014) or recruit a transcriptional repressor as suggested for the COOLAIR locus in Arabidopsis (Sun et al., 2013). Reduced transcription could then result in the accumulation of repressive histone marks. It is also possible that silencing occurs due to the ability of RNA:DNA hybrids to recruit H3S10P, a mark of chromatin compaction (Castellano-Pozo et al., 2013).

An alternative model for FX gene silencing is suggested by what is known about silencing of the RASSF1A gene in humans. This is accomplished by the formation of RNA:DNA hybrid just downstream of the start of transcription by transcription from an antisense promoter (Beckedorff et al., 2013). The tethered RNA binds and recruits Polycomb repressive complex 2 (PRC2) to the RASSF1A promoter resulting in gene silencing. An example of how an RNA:DNA hybrid could operate to recruit factors that initiate silencing at the FMR1 locus is illustrated in the right hand panel of Figure 2B. The FMR1 $5^{\prime}$ end has some of the hallmarks of typical PRC2 target genes, including a high $\mathrm{G}+\mathrm{C}$-content and a high density of CpG residues (Mendenhall et al., 2010). Furthermore, there is evidence to suggest that many RNAs that bind to PRC2 and lead to gene silencing in cis form stem-loop structures (Kanhere et al., 2010) that are reminiscent of those formed by CGG-RNA (Handa et al., 2003). Other candidate epigenetic modifiers that bind structured RNAs could act in much the same way, including Suv4-20h2, the methylase responsible for H4K20 trimethylation. Recruitment of this histone methyltransferase by a long non-coding RNA (lncRNA) is thought to be the trigger for silencing of rDNA repeats and intracisternal A-particle (IAP) elements (Bierhoff et al., 2014). 
Whatever the gene silencing mechanism, evidence suggests that the extent of this process can be very variable. Some FM carriers do not complete the gene silencing process, showing evidence of H3K9 dimethylation, but no DNA methylation (Tabolacci et al., 2008a). These individuals tend to be unaffected or less affected than those having alleles that are fully silenced. Other individuals show methylation mosaicism in which some alleles are more heavily methylated than others (McConkie-Rosell et al., 1993; Nolin et al., 1994; Rousseau et al., 1994; de Vries et al., 1996; Tassone et al., 1999; Pretto et al., 2014). Since unmethylated alleles often still make significant amounts of FMRP (Tassone et al., 2000a; Tabolacci et al., 2008a), methylation mosaicism likely contributes to variation in the levels of FMRP expressed in patient cells that is potentially a source of variability in the clinical presentation.

A number of epigenetic modifying drugs with the potential to reactivate the FMR1 gene are in clinical trials for the treatment of life-threatening diseases like cancer, as well as other repeat expansion diseases with a high early mortality like FRDA and spinal muscular atrophy (Hahnen et al., 2006; Deutsch et al., 2008). Phase I clinical trials of one such compound, the HDAC inhibitor RG2833, showed that it could reduce epigenetic gene repression in FRDA patients. It is likely that many of these epigenetic modifiers will be too risky to use in a disorder like FXS that is not life threatening. However, there are others in the pipeline that may be both therapeutically useful and relatively non-toxic. One such compound, nicotinamide (Vitamin B3), an inhibitor of SIRT1, an enzyme we have shown to be important in FX gene silencing (Biacsi et al., 2008), is currently in clinical trials for the treatment of FRDA (http://www.clinicaltrials.gov/ct2/show/NCT01589809). The development of better inhibitors of SIRT1 as well as other epigenetic modifying enzymes in the silencing pathway may one day provide a therapeutic option for the treatment of FXS. Recently a small molecule that stabilizes the structures formed by FX repeats in the FMR1 transcript and thus reduces R-loop formation, has been shown to block gene silencing (Colak et al., 2014). While this molecule was unable to reactivate a silenced allele, it is possible that in combination with other epigenetic modifiers it may ultimately have therapeutic potential. Of course, any benefit to be gained by reactivation of the FX allele would have to be offset by the risk posed by expression of FMR1 mRNA with long CGG-repeat tracts.

\section{CHROMOSOME FRAGILITY}

Fragile sites are constrictions, gaps or breaks that are seen in metaphase chromosomes [see (Lukusa and Fryns, 2008) for a comprehensive review]. Many such sites are present in the human genome where they are frequently associated with chromosome breakpoints and translocations. Fragile sites are said to be common or rare based on their incidence in the population, with common fragile sites being ubiquitously present and rare fragile sites being confined to a much smaller subset of individuals. Fragile sites are usually classified in terms of which agents most effectively induce their expression. These agents include folate, aphidicolin, distamycin, and bromodeoxyuridine. The presence of a folate-sensitive fragile site on the long arm of the X chromosome in individuals with FXS was noted many decades before the
FMR1 gene was identified (Howard-Peebles and Stoddard, 1979; Sutherland and Ashforth, 1979; Turner et al., 1980). The fragile site can be seen in as many as $20 \%$ of cells depending on repeat number and growth conditions. This indicates that the underlying event is likely to be extremely frequent.

There is reason to think that the high incidence of TS seen in FM females (Dobkin et al., 2009) could be a direct consequence of the chromosome fragility. For example, simultaneous breaks on both chromatids can lead to chromatid fusion, and the generation of a dicentric chromosome. The two centromeres of the chromosome will try to migrate toward opposite poles at anaphase. Chromosome aneuploidy can then occur through non-disjunction, if the dicentric chromatid is only released from one pole, resulting in one daughter cell receiving the whole chromosome at the expense of the other daughter cell. Alternatively, if the dicentric chromatid frees itself from the microtubules of both spindle poles, it can be lost from both cells as a result of anaphase lagging.

There are some clues as to what causes the FX allele to become fragile and/or break. Folate is a critical precursor for the synthesis of thymidine and too much or too little of this vitamin can cause nucleotide pool imbalances (James et al., 1992) that might cause or exacerbate problems with replication (Chabosseau et al., 2011) through the repeat. The FX repeats cause replication fork stalling in yeast and human cells (Voineagu et al., 2009). They also block initiation of replication from a major ORI located just upstream of the repeat in the FMR1 gene itself and likely affect replication fork progression as well (Yudkin et al., 2014). This block is seen even in cells grown in the absence of folatestress and thus the replication problem is likely an intrinsic feature of the repeats that occurs frequently under normal growth conditions. Folate-stress could induce fragile site expression by making an already late-replicating region (Webb, 1992; Hansen et al., 1993) replicate even later. This would increase the fraction of cells that enter mitosis before replication of this region is complete. What is responsible for the replication defect is unknown. R-loops, such as those formed by the FX repeats (Groh et al., 2014; Loomis et al., 2014), can stall DNA replication (Gan et al., 2011). However, chromosome fragility is more frequently seen on methylated FM alleles than unmethylated ones (Yudkin et al., 2014). It is unclear whether the residual transcription from methylated alleles is sufficient to cause stalling at a significant frequency. It is also possible that the secondary structures that can be formed by the FX repeat are responsible for the replication problem since they do form very stable blocks to DNA polymerases in vitro (Usdin and Woodford, 1995). Whatever their molecular basis, stalled replication forks can result in doublestrand breaks generated in an attempt to rescue the fork. Such breaks could then lead to sister chromatid fusion and ultimately the loss of the $\mathrm{X}$ chromosome from a fraction of the daughter cells.

Thus each cell division poses a risk for the loss of the chromosome carrying the FM. If chromosome loss happens in the very early embryo, it is unlikely to survive (Hook and Warburton, 1983). However, if it occurs later in development, females will be mosaic for the loss of the $\mathrm{X}$ chromosome. The extent to which she would experience the symptoms of TS would depend on the fraction of her cells that are $45, \mathrm{X} 0$. 


\section{CONCLUDING REMARKS}

As evidenced above, the presence of CGG/CGG -repeats at the 5' end of the FMR1 gene causes a number of genetic and epigenetic changes that can have profound effects on the FMR1 locus and FMR1 expression. These effects are, for the most part, expressed in direct proportion to the number of repeats in the affected allele. Thus unlike point mutations or insertions/deletions, the dynamic nature of the expansion mutation essentially makes the FX repeat a continuous variable, at least on the population level. Thus perhaps it should not be surprising that the symptoms seen in carriers of larger than normal numbers of CGG/CCG repeats form a continuum. Therefore, it may be more useful to think of as these individuals being somewhere on the Fragile X spectrum, such that the symptoms experienced may range from a risk of neurodegenerative changes or diminished ovarian function at one end of the spectrum to severe neurodevelopmental problems at the other. The range of symptoms displayed would depend on the number of repeats in the affected allele and the extent of somatic mosaicism that would impact the amount of FMR1 mRNA and FMRP produced in critical cell types. A better understanding of all of the biological consequences of the repeats at both the DNA and RNA level may help us understand which of the effects can be mitigated and which ones cannot.

\section{REFERENCES}

Aamann, M. D., Muftuoglu, M., Bohr, V. A., and Stevnsner, T. (2013). Multiple interaction partners for Cockayne syndrome proteins: implications for genome and transcriptome maintenance. Mech. Ageing Dev. 134, 212-224. doi: 10.1016/j.mad.2013.03.009

Alisch, R. S., Wang, T., Chopra, P., Visootsak, J., Conneely, K. N., and Warren, S. T. (2013). Genome-wide analysis validates aberrant methylation in fragile X syndrome is specific to the FMR1 locus. BMC Med. Genet. 14:18. doi: 10.1186/1471-2350-14-18

Allen, E. G., Sullivan, A. K., Marcus, M., Small, C., Dominguez, C., Epstein, M. P., etal. (2007). Examination of reproductive aging milestones among women who carry the FMR1 premutation. Hum. Reprod. 22, 2142-2152. doi: 10.1093/humrep/dem 148

Ashley-Koch, A. E., Robinson, H., Glicksman, A. E., Nolin, S. L., Schwartz, C. E., Brown, W. T., et al. (1998). Examination of factors associated with instability of the FMR1 CGG repeat. Am. J. Hum. Genet. 63, 776-785. doi: 10.1086/ 302018

Barasoain, M., Barrenetxea, G., Huerta, I., Telez, M., Carrillo, A., Perez, C., et al. (2013). Study of FMR1 gene association with ovarian dysfunction in a sample from the Basque Country. Gene 521, 145-149. doi: 10.1016/j.gene.2013. 03.032

Bear, M. F., Huber, K. M., and Warren, S. T. (2004). The mGluR theory of fragile X mental retardation. Trends Neurosci. 27, 370-377. doi: 10.1016/j.tins.2004.04.009

Beckedorff, F. C., Ayupe, A. C., Crocci-Souza, R., Amaral, M. S., Nakaya, H. I., Soltys, D. T., et al. (2013). The intronic long noncoding RNA ANRASSF1 recruits PRC2 to the RASSF1A promoter, reducing the expression of RASSF1A and increasing cell proliferation. PLoS Genet. 9:e1003705. doi: 10.1371/journal.pgen.1003705

Beilina, A., Tassone, F., Schwartz, P. H., Sahota, P., and Hagerman, P. J. (2004). Redistribution of transcription start sites within the $F M R 1$ promoter region with expansion of the downstream CGG-repeat element. Hum. Mol. Genet. 13, 543 549. doi: 10.1093/hmg/ddh053

Bennett, C. E., Conway, G. S., Macpherson, J. N., Jacobs, P. A., and Murray, A. (2010). Intermediate sized CGG repeats are not a common cause of idiopathic premature ovarian failure. Hum. Reprod. 25, 1335-1338. doi: 10.1093/humrep/deq058

Berry-Kravis, E. (2002). Epilepsy in fragile X syndrome. Dev. Med. Child Neurol. 44, 724-728. doi: 10.1111/j.1469-8749.2002.tb00277.x

Berry-Kravis, E., Potanos, K., Weinberg, D., Zhou, L., and Goetz, C. G. (2005). Fragile $\mathrm{X}$-associated tremor/ataxia syndrome in sisters related to $\mathrm{X}$-inactivation. Ann. Neurol. 57, 144-147. doi: 10.1002/ana.20360
Biacsi, R., Kumari, D., and Usdin, K. (2008). SIRT1 inhibition alleviates gene silencing in Fragile X mental retardation syndrome. PLoS Genet. 4:e1000017. doi: 10.1371/journal.pgen.1000017

Bierhoff, H., Dammert, M. A., Brocks, D., Dambacher, S., Schotta, G., and Grummt, I. (2014). Quiescence-induced LncRNAs trigger H4K20 trimethylation and transcriptional silencing. Mol. Cell 54, 675-682. doi: 10.1016/j.molcel.2014.03.032

Bodega, B., Bione, S., Dalpra, L., Toniolo, D., Ornaghi, F., Vegetti, W., et al. (2006). Influence of intermediate and uninterrupted FMR1 CGG expansions in premature ovarian failure manifestation. Hum. Reprod. 21, 952-957. doi: 10.1016/j.molcel.2014.03.032

Bontekoe, C. J., De Graaff, E., Nieuwenhuizen, I. M., Willemsen, R., and Oostra, B. A. (1997). FMR1 premutation allele (CGG) 81 is stable in mice. Eur. J. Hum. Genet. 5, 293-298. doi: 10.1093/humrep/dei432

Braun, K., and Segal, M. (2000). FMRP involvement in formation of synapses among cultured hippocampal neurons. Cereb. Cortex 10, 1045-1052. doi: 10.1093/cercor/10.10.1045

Bretherick, K. L., Fluker, M. R., and Robinson, W. P. (2005). FMR1 repeat sizes in the gray zone and high end of the normal range are associated with premature ovarian failure. Hum. Genet. 117, 376-382. doi: 10.1007/s00439-0051326-8

Brouwer, J. R., Huizer, K., Severijnen, L. A., Hukema, R. K., Berman, R. F., Oostra, B. A., et al. (2008). CGG-repeat length and neuropathological and molecular correlates in a mouse model for fragile X-associated tremor/ataxia syndrome. J. Neurochem. 107, 1671-1682. doi: 10.1111/j.1471-4159.2008.05747.x

Bulut-Karslioglu, A., Perrera, V., Scaranaro, M., De La Rosa-Velazquez, I. A., Van De Nobelen, S., Shukeir, N., et al. (2012). A transcription factor-based mechanism for mouse heterochromatin formation. Nat. Struct. Mol. Biol. 19, 1023-1030. doi: $10.1038 / \mathrm{nsmb} .2382$

Castellano-Pozo, M., Santos-Pereira, J. M., Rondon, A. G., Barroso, S., Andujar, E., Perez-Alegre, M., et al. (2013). R loops are linked to histone H3 S10 phosphorylation and chromatin condensation. Mol. Cell 52, 583-590. doi: 10.1016/j.molcel.2013.10.006

Chabosseau, P., Buhagiar-Labarchede, G., Onclercq-Delic, R., Lambert, S., Debatisse, M., Brison, O., et al. (2011). Pyrimidine pool imbalance induced by BLM helicase deficiency contributes to genetic instability in Bloom syndrome. Nat. Commun. 2, 368. doi: 10.1038/ncomms1363

Chen, X., Mariappan, S. V., Catasti, P., Ratliff, R., Moyzis, R. K., Laayoun, A., et al. (1995). Hairpins are formed by the single DNA strands of the fragile X triplet repeats: structure and biological implications. Proc. Natl. Acad. Sci. U.S.A. 92, 5199-5203. doi: 10.1073/pnas.92.11.5199

Chiurazzi, P., Pomponi, M. G., Pietrobono, R., Bakker, C. E., Neri, G., and Oostra, B. A. (1999). Synergistic effect of histone hyperacetylation and DNA demethylation in the reactivation of the FMR1 gene. Hum. Mol. Genet. 8, 2317-2323. doi: 10.1093/hmg/8.12.2317

Chiurazzi, P., Pomponi, M. G., Willemsen, R., Oostra, B. A., and Neri, G. (1998). In vitro reactivation of the FMR1 gene involved in fragile X syndrome. Hum. Mol. Genet. 7, 109-113. doi: 10.1093/hmg/7.1.109

Chonchaiya, W., Au, J., Schneider, A., Hessl, D., Harris, S. W., Laird, M., et al. (2012). Increased prevalence of seizures in boys who were probands with the FMR1 premutation and co-morbid autism spectrum disorder. Hum. Genet. 131, 581-589. doi: 10.1007/s00439-011-1106-6

Clifford, S., Dissanayake, C., Bui, Q. M., Huggins, R., Taylor, A. K., and Loesch, D. Z. (2007). Autism spectrum phenotype in males and females with fragile $\mathrm{X}$ full mutation and premutation. J. Autism Dev. Disord. 37, 738-747. doi: 10.1007/s10803-006-0205-Z

Coffee, B., Zhang, F., Warren, S. T., and Reines, D. (1999). Acetylated histones are associated with FMR1 in normal but not fragile X-syndrome cells. Nat. Genet. 22, 98-101. doi: 10.1038/8807

Coffey, S. M., Cook, K., Tartaglia, N., Tassone, F., Nguyen, D. V., Pan, R., et al. (2008). Expanded clinical phenotype of women with the FMR1 premutation. Am. J. Med. Genet. A 146A, 1009-1016. doi: 10.1002/ajmg.a.32060

Cohen, I. L., Nolin, S. L., Sudhalter, V., Ding, X. H., Dobkin, C. S., and Brown, W. T. (1996). Mosaicism for the FMR1 gene influences adaptive skills development in fragile X-affected males. Am. J. Med. Genet. 64, 365-369. doi: 10.1002/(SICI) 1096-8628(19960809)64:2<365::AID-AJMG26>3.0.CO;2-C

Colak, D., Zaninovic, N., Cohen, M. S., Rosenwaks, Z., Yang, W. Y., Gerhardt, J., et al. (2014). Promoter-bound trinucleotide repeat mRNA drives epigenetic silencing in fragile X syndrome. Science 343, 1002-1005. doi: 10.1126/science.1245831 
Comery, T. A., Harris, J. B., Willems, P. J., Oostra, B. A., Irwin, S. A., Weiler, I. J., et al. (1997). Abnormal dendritic spines in fragile X knockout mice: maturation and pruning deficits. Proc. Natl. Acad. Sci. U.S.A. 94, 5401-5404. doi: 10.1073/pnas.94.10.5401

De Boulle, K., Verkerk, A. J., Reyniers, E., Vits, L., Hendrickx, J., Van Roy, B., et al (1993). A point mutation in the FMR-1 gene associated with fragile X mental retardation. Nat. Genet. 3, 31-35. doi: 10.1038/ng0193-31

de Graaff, E., De Vries, B. B., Willemsen, R., Van Hemel, J. O., Mohkamsing, S., Oostra, B. A., etal. (1996). The fragile X phenotype in a mosaic male with a deletion showing expression of the FMR 1 protein in $28 \%$ of the cells. Am. J. Med. Genet. 64, 302-308. doi: 10.1002/(SICI)1096-8628(19960809)64:2<302::AIDAJMG14>3.0.CO;2-J

Deutsch, S. I., Rosse, R. B., Mastropaolo, J., Long, K. D., and Gaskins, B. L. (2008). Epigenetic therapeutic strategies for the treatment of neuropsychiatric disorders: ready for prime time? Clin. Neuropharmacol. 31, 104-119. doi: 10.1097/WNF.0b013e318067e255

de Vries, B. B., Jansen, C. C., Duits, A. A., Verheij, C., Willemsen, R., Van Hemel, J. O., et al. (1996). Variable FMR1 gene methylation of large expansions leads to variable phenotype in three males from one fragile X family. J. Med. Genet. 33, 1007-1010. doi: 10.1136/jmg.33.12.1007

Devys, D., Biancalana, V., Rousseau, F., Boue, J., Mandel, J. L., and Oberle, I. (1992). Analysis of full fragile X mutations in fetal tissues and monozygotic twins indicate that abnormal methylation and somatic heterogeneity are established early in development. Am. J. Med. Genet. 43, 208-216. doi: 10.1002/ajmg. 1320430134

Dobkin, C., Radu, G., Ding, X. H., Brown, W. T., and Nolin, S. L. (2009). Fragile $\mathrm{X}$ prenatal analyses show full mutation females at high risk for mosaic Turner syndrome: fragile X leads to chromosome loss. Am. J. Med. Genet. 149A, 2152 2157. doi: 10.1002/ajmg.a.33011

Dobkin, C. S., Nolin, S. L., Cohen, I., Sudhalter, V., Bialer, M. G., Ding, X. H., et al. (1996). Tissue differences in fragile X mosaics: mosaicism in blood cells may differ greatly from skin. Am. J. Med. Genet. 64, 296-301. doi: 10.1002/(SICI) 10968628(19960809)64:2<296::AID-AJMG13>3.0.CO;2-A

Dolen, G., and Bear, M. F. (2008). Role for metabotropic glutamate receptor 5 (mGluR5) in the pathogenesis of fragile X syndrome. J. Physiol. 586, 1503-1508. doi: 10.1113/jphysiol.2008.150722

Dong, K. B., Maksakova, I. A., Mohn, F., Leung, D., Appanah, R., Lee, S., et al (2008). DNA methylation in ES cells requires the lysine methyltransferase G9a but not its catalytic activity. EMBO J. 27, 2691-2701. doi: 10.1038/emboj. 2008.193

Du, J., Campau, E., Soragni, E., Ku, S., Puckett, J. W., Dervan, P. B., et al. (2012). Role of mismatch repair enzymes in GAA.TTC triplet-repeat expansion in Friedreich ataxia induced pluripotent stem cells. J. Biol. Chem. 287, 29861-29872. doi: 10.1074/jbc.M112.391961

Dunn, K., and Griffith, J. D. (1980). The presence of RNA in a double helix inhibits its interaction with histone protein. Nucleic Acids Res. 11, 555-566. doi 10.1093/nar/8.3.555

Eichler, E. E., Holden, J. J., Popovich, B. W., Reiss, A. L., Snow, K., Thibodeau, S. N., et al. (1994). Length of uninterrupted CGG repeats determines instability in the FMR1 gene. Nat. Genet. 8, 88-94. doi: 10.1038/ng0994-88

Eiges, R., Urbach, A., Malcov, M., Frumkin, T., Schwartz, T., Amit, A., et al. (2007). Developmental study of fragile X syndrome using human embryonic stem cells derived from preimplantation genetically diagnosed embryos. Cell Stem Cell 1, 568-577. doi: 10.1016/j.stem.2007.09.001

Ennis, S., Ward, D., and Murray, A. (2006). Nonlinear association between CGG repeat number and age of menopause in FMR1 premutation carriers. Eur. J. Hum. Genet. 14, 253-255. doi: 10.1038/sj.ejhg.5201510

Entezam, A., Biacsi, R., Orrison, B., Saha, T., Hoffman, G. E., Grabczyk, E., et al. (2007). Regional FMRP deficits and large repeat expansions into the full mutation range in a new Fragile X premutation mouse model. Gene 395, 125-134. doi: 10.1016/j.gene.2007.02.026

Entezam, A., Lokanga, A. R., Le, W., Hoffman, G., and Usdin, K. (2010). Potassium bromate, a potent DNA oxidizing agent, exacerbates germline repeat expansion in a fragile X premutation mouse model. Hum. Mutat. 31, 611-616. doi: 10.1002/humu.21237

Entezam, A., and Usdin, K. (2008). ATR protects the genome against CGG.CCGrepeat expansion in Fragile X premutation mice. Nucleic Acids Res. 36, 1050-1056. doi: $10.1093 / \mathrm{nar} / \mathrm{gkm} 1136$
Entezam, A., and Usdin, K. (2009). ATM and ATR protect the genome against two different types of tandem repeat instability in Fragile X premutation mice. Nucleic Acids Res. 37, 6371-6377. doi: 10.1093/nar/gkp666

Epsztejn-Litman, S., Feldman, N., Abu-Remaileh, M., Shufaro, Y., Gerson, A., Ueda, J., et al. (2008). De novo DNA methylation promoted by G9a prevents reprogramming of embryonically silenced genes. Nat. Struct. Mol. Biol. 15, 1176-1183. doi: 10.1038/nsmb.1476

Fan, H., Booker, J. K., Mccandless, S. E., Shashi, V., Fleming, A., and Farber, R. A. (2005). Mosaicism for an FMR1 gene deletion in a fragile X female. Am. J. Med. Genet. A 136, 214-217. doi: 10.1002/ajmg.a.30807

Farzin, F., Perry, H., Hessl, D., Loesch, D., Cohen, J., Bacalman, S., et al. (2006). Autism spectrum disorders and attention-deficit/hyperactivity disorder in boys with the fragile X premutation. J. Dev. Behav. Pediatr. 27, S137-S144. doi: 10.1097/00004703-200604002-00012

Feldman, N., Gerson, A., Fang, J., Li, E., Zhang, Y., Shinkai, Y., et al. (2006). G9a-mediated irreversible epigenetic inactivation of Oct-3/4 during early embryogenesis. Nat. Cell Biol. 8, 188-194. doi: 10.1038/ncb1353

Ferreira, S. I., Pires, L. M., Ferrao, J., Sa, J., Serra, A., and Carreira, I. M. (2013). Mosaicism for FMR1 gene full mutation and intermediate allele in a female foetus: a postzygotic retraction event. Gene 527, 421-425. doi: 10.1016/j.gene.2013.05.079

Fleming, K., Riser, D. K., Kumari, D., and Usdin, K. (2003). Instability of the fragile $\mathrm{X}$ syndrome repeat in mice: the effect of age, diet and mutations in genes that affect DNA replication, recombination and repair proficiency. Cytogenet. Genome Res. 100, 140-146. doi: 10.1159/000072848

Foiry, L., Dong, L., Savouret, C., Hubert, L., Te Riele, H., Junien, C., et al. (2006). Msh3 is a limiting factor in the formation of intergenerational CTG expansions in DM1 transgenic mice. Hum. Genet. 119, 520-526. doi: 10.1007/s00439-0060164-7

Fojtik, P., and Vorlickova, M. (2001). The fragile X chromosome (GCC) repeat folds into a DNA tetraplex at neutral pH. Nucleic Acids Res. 29, 4684-4690. doi: 10.1093/nar/29.22.4684

Fortune, M. T., Vassilopoulos, C., Coolbaugh, M. I., Siciliano, M. J., and Monckton, D. G. (2000). Dramatic, expansion-biased, age-dependent, tissue-specific somatic mosaicism in a transgenic mouse model of triplet repeat instability. Hum. Mol. Genet. 9, 439-445. doi: 10.1093/hmg/9.3.439

Fry, M., and Loeb, L. A. (1994). The fragile X syndrome d(CGG) $n$ nucleotide repeats form a stable tetrahelical structure. Proc. Natl. Acad. Sci. U.S.A. 91, 4950-4954. doi: 10.1073/pnas.91.11.4950

Fry, M., and Usdin, K. (2006). Human Nucleotide Expansion Disorders. Heidelberg: Springer. doi: 10.1007/3-540-33336-3

Fu, Y. H., Kuhl, D. P., Pizzuti, A., Pieretti, M., Sutcliffe, J. S., Richards, S., et al. (1991). Variation of the CGG repeat at the fragile $X$ site results in genetic instability: resolution of the Sherman paradox. Cell 67, 1047-1058. doi: 10.1016/0092-8674(91)90283-5

Gan, W., Guan, Z., Liu, J., Gui, T., Shen, K., Manley, J. L., et al. (2011). R-loop-mediated genomic instability is caused by impairment of replication fork progression. Genes Dev. 25, 2041-2056. doi: 10.1101/gad.17010011

Garcia Arocena, D., De Diego, Y., Oostra, B. A., Willemsen, R., and Mirta Rodriguez, M. (2000). A fragile X case with an amplification/deletion mosaic pattern. Hum. Genet. 106, 366-369. doi: 10.1007/s004390051052

Gasteiger, M., Grasbon-Frodl, E., Neitzel, B., Kooy, F., and Holinski-Feder, E. (2003). FMR1 gene deletion/reversion: a pitfall of fragile X carrier testing. Genet. Test. 7, 303-308. doi: 10.1089/109065703322783653

Gerhardt, J., Tomishima, M. J., Zaninovic, N., Colak, D., Yan, Z., Zhan, Q., et al. (2014). The DNA replication program is altered at the FMR1 locus in fragile $\mathrm{X}$ embryonic stem cells. Mol. Cell 53, 19-31. doi: 10.1016/j.molcel.2013.10.029

Govaerts, L. C., Smit, A. E., Saris, J. J., Vanderwerf, F., Willemsen, R., Bakker, C. E., et al. (2007). Exceptional good cognitive and phenotypic profile in a male carrying a mosaic mutation in the FMR1 gene. Clin. Genet. 72, 138-144. doi: 10.1111/j.1399-0004.2007.00829.x

Grasso, M., Faravelli, F., Lo Nigro, C., Chiurazzi, P., Sperandeo, M. P., Argusti, A., et al. (1999). Mosaicism for the full mutation and a microdeletion involving the CGG repeat and flanking sequences in the FMR1 gene in eight fragile X patients. Am. J. Med. Genet. 85, 311-316. doi: 10.1002/(SICI)10968628(19990730)85:3<311::AID-AJMG24>3.0.CO;2-A

Grigsby, J., Brega, A. G., Jacquemont, S., Loesch, D. Z., Leehey, M. A., Goodrich, G. K., et al. (2006). Impairment in the cognitive functioning of men with fragile 
X-associated tremor/ataxia syndrome (FXTAS). J. Neurol. Sci. 248, 227-233. doi: 10.1016/j.jns.2006.05.016

Grigsby, J., Brega, A. G., Leehey, M. A., Goodrich, G. K., Jacquemont, S., Loesch, D. Z., et al. (2007). Impairment of executive cognitive functioning in males with fragile X-associated tremor/ataxia syndrome. Mov. Disord. 22, 645-650. doi: 10.1002/mds.21359

Groh, M., Lufino, M. M., Wade-Martins, R., and Gromak, N. (2014). R-loops associated with triplet repeat expansions promote gene silencing in Friedreich ataxia and fragile X syndrome. PLoS Genet. 10:e1004318. doi: 10.1371/journal.pgen.1004318

Gu, Y., Lugenbeel, K. A., Vockley, J. G., Grody, W. W., and Nelson, D. L. (1994). A de novo deletion in FMR1 in a patient with developmental delay. Hum. Mol. Genet. 3, 1705-1706. doi: 10.1093/hmg/3.9.1705

Haeusler, A. R., Donnelly, C. J., Periz, G., Simko, E. A., Shaw, P. G., Kim, M. S., et al. (2014). C9orf72 nucleotide repeat structures initiate molecular cascades of disease. Nature 507, 195-200. doi: 10.1038/nature13124

Hagerman, P. (2013). Fragile X-associated tremor/ataxia syndrome (FXTAS): pathology and mechanisms. Acta Neuropathol. 126, 1-19. doi: 10.1007/s00401013-1138-1

Hagerman, R. J., and Hagerman, P. J. (2008). Testing for fragile X gene mutations throughout the life span. JAMA 300, 2419-2421. doi: 10.1001/jama.2008.684

Hagerman, R. J., Hull, C. E., Safanda, J. F., Carpenter, I., Staley, L. W., O’Connor, R. A., et al. (1994). High functioning fragile $\mathrm{X}$ males: demonstration of an unmethylated fully expanded FMR-1 mutation associated with protein expression. Am. J. Med. Genet. 51, 298-308. doi: 10.1002/ajmg.1320510404

Hagerman, R. J., Staley, L. W., O’Conner, R., Lugenbeel, K., Nelson, D., Mclean, S D., et al. (1996). Learning-disabled males with a fragile X CGG expansion in the upper premutation size range. Pediatrics 97, 122-126.

Hahnen, E., Eyupoglu, I. Y., Brichta, L., Haastert, K., Trankle, C., Siebzehnrubl, F. A., et al. (2006). In vitro and ex vivo evaluation of second-generation histone deacetylase inhibitors for the treatment of spinal muscular atrophy. J. Neurochem. 98, 193-202. doi: 10.1111/j.1471-4159.2006.03868.x

Halabi, A., Ditch, S., Wang, J., and Grabczyk, E. (2012). DNA mismatch repair complex MutS $\beta$ promotes GAA.TTC repeat expansion in human cells. J. Biol. Chem. 287, 29958-29967. doi: 10.1074/jbc.M112.356758

Hall, D., Tassone, F., Klepitskaya, O., and Leehey, M. (2012). Fragile X-associated tremor ataxia syndrome in FMR1 gray zone allele carriers. Mov. Disord. 27, 296-300. doi: 10.1002/mds.24021

Hall, D. A., Berry-Kravis, E., Zhang, W., Tassone, F., Spector, E., Zerbe, G., etal. (2011). FMR1 gray-zone alleles: association with Parkinson's disease in women? Mov. Disord. 26, 1900-1906. doi: 10.1002/mds. 23755

Handa, V., Saha, T., and Usdin, K. (2003). The fragile X syndrome repeats form RNA hairpins that do not activate the interferon-inducible protein kinase, PKR but are cut by Dicer. Nucleic Acids Res. 31, 6243-6248. doi: 10.1093/nar/ gkg818

Hansen, R. S., Canfield, T. K., Lamb, M. M., Gartler, S. M., and Laird, C. D. (1993). Association of fragile X syndrome with delayed replication of the FMR1 gene. Cell 73, 1403-1409. doi: 10.1016/0092-8674(93)90365-W

Heitz, D., Devys, D., Imbert, G., Kretz, C., and Mandel, J. L. (1992). Inheritance of the fragile $\mathrm{X}$ syndrome: size of the fragile $\mathrm{X}$ premutation is a major determinant of the transition to full mutation. J. Med. Genet. 29, 794-801. doi: 10.1136/jmg.29.11.794

Hessl, D., Rivera, S., Koldewyn, K., Cordeiro, L., Adams, J., Tassone, F., et al. (2007). Amygdala dysfunction in men with the fragile X premutation. Brain 130, 404-416. doi: 10.1093/brain/awl338

Hook, E. B., and Warburton, D. (1983). The distribution of chromosomal genotypes associated with Turner's syndrome: livebirth prevalence rates and evidence for diminished fetal mortality and severity in genotypes associated with structural $\mathrm{X}$ abnormalities or mosaicism. Hum. Genet. 64, 24-27. doi: 10.1007/BF00289473

Howard-Peebles, P. N., and Stoddard, G. R. (1979). X-linked mental retardation with macro-orchidism and marker X chromosomes. Hum. Mutat. 50, 247-251.

Huang, C. C., Chiribau, C. B., Majumder, M., Chiang, C. M., Wek, R. C., Kelm, R. J., et al. (2009). A bifunctional intronic element regulates the expression of the arginine/lysine transporter Cat-1 via mechanisms involving the purine-rich element binding protein A (Pur alpha). J. Biol. Chem. 284, 32312-32320. doi: 10.1074/jbc.M109.024471

Huang, W., Luo, S., Ou, J., Zhu, F., Xia, Y., Xue, J., et al. (2014). Correlation between FMR1 expression and clinical phenotype in discordant dichorionic-diamniotic monozygotic twin sisters with the fragile X mutation. J. Med. Genet. 51, 159-164. doi: 10.1136/jmedgenet-2013-101978

Irwin, S. A., Galvez, R., and Greenough, W. T. (2000). Dendritic spine structural anomalies in fragile-X mental retardation syndrome. Cereb. Cortex 10, 10381044. doi: $10.1093 /$ cercor/10.10.1038

Ishiguro, H., Yamada, K., Sawada, H., Nishii, K., Ichino, N., Sawada, M., et al. (2001). Age-dependent and tissue-specific CAG repeat instability occurs in mouse knockin for a mutant Huntington's disease gene. J. Neurosci. Res. 65, 289-297. doi: 10.1002/jnr.1153

Ishizuka, B., Okamoto, N., Hamada, N., Sugishita, Y., Saito, J., Takahashi, N., etal. (2011). Number of CGG repeats in the FMR1 gene of Japanese patients with primary ovarian insufficiency. Fertil. Steril. 96, 1170-1174. doi: 10.1016/j.fertnstert.2011.08.028

Iwahashi, C. K., Yasui, D. H., An, H. J., Greco, C. M., Tassone, F., Nannen, K., et al. (2006). Protein composition of the intranuclear inclusions of FXTAS. Brain 129, 256-271. doi: 10.1093/brain/awh650

Jacquemont, S. (2005). Screening for FXTAS. Eur. J. Hum. Genet. 13, 2-3. doi: 10.1038/sj.ejhg.5201318

Jacquemont, S., Hagerman, R. J., Leehey, M. A., Hall, D. A., Levine, R. A., Brunberg, J. A., et al. (2004). Penetrance of the fragile X-associated tremor/ataxia syndrome in a premutation carrier population. JAMA 291, 460-469. doi: 10.1001/jama.291.4.460

James, S. J., Cross, D. R., and Miller, B. J. (1992). Alterations in nucleotide pools in rats fed diets deficient in choline, methionine and/or folic acid. Carcinogenesis 13, 2471-2474. doi: 10.1093/carcin/13.12.2471

Jarem, D. A., Huckaby, L. V., and Delaney, S. (2010). AGG interruptions in $(\mathrm{CGG})_{n}$ DNA repeat tracts modulate the structure and thermodynamics of non-B conformations in vitro. Biochemistry 49, 6826-6837. doi: 10.1021/bi10 07782

Jin, P., Duan, R., Qurashi, A., Qin, Y., Tian, D., Rosser, T. C., et al. (2007). Pur $\alpha$ binds to rCGG repeats and modulates repeat-mediated neurodegeneration in a Drosophila model of fragile X tremor/ataxia syndrome. Neuron 55, 556-564. doi: 10.1016/j.neuron.2007.07.020

Kanhere, A., Viiri, K., Araujo, C. C., Rasaiyaah, J., Bouwman, R. D., Whyte, W. A., et al. (2010). Short RNAs are transcribed from repressed polycomb target genes and interact with polycomb repressive complex-2. Mol. Cell 38, 675-688. doi: 10.1016/j.molcel.2010.03.019

Karimov, C. B., Moragianni, V. A., Cronister, A., Srouji, S., Petrozza, J., Racowsky, C., et al. (2011). Increased frequency of occult fragile X-associated primary ovarian insufficiency in infertile women with evidence of impaired ovarian function. Hum. Reprod. 26, 2077-2083. doi: 10.1093/humrep/der168

Kenneson, A., Zhang, F., Hagedorn, C. H., and Warren, S. T. (2001). Reduced FMRP and increased FMR1 transcription is proportionally associated with CGG repeat number in intermediate-length and premutation carriers. Hum. Mol. Genet. 10, 1449-1454. doi: 10.1093/hmg/10.14.1449

Kim, D. H., Villeneuve, L. M., Morris, K. V., and Rossi, J. J. (2006). Argonaute-1 directs siRNA-mediated transcriptional gene silencing in human cells. Nat. Struct. Mol. Biol. 13, 793-797. doi: 10.1038/nsmb1142

Kim, S. Y., Burris, J., Bassal, F., Koldewyn, K., Chattarji, S., Tassone, F., et al. (2014) Fear-specific amygdala function in children and adolescents on the fragile X spectrum: a dosage response of the FMR1 gene. Cereb. Cortex 24, 600-613. doi: 10.1093/cercor/bhs341

Kovtun, I. V., Liu, Y., Bjoras, M., Klungland, A., Wilson, S. H., and Mcmurray, C. T. (2007). OGG1 initiates age-dependent CAG trinucleotide expansion in somatic cells. Nature 447, 447-452. doi: 10.1038/nature05778

Kovtun, I. V., and McMurray, C. T. (2001). Trinucleotide expansion in haploid germ cells by gap repair. Nat. Genet. 27, 407-411. doi: 10.1038/86906

Kumari, D., and Usdin, K. (2010). The distribution of repressive histone modifications on silenced FMR1 alleles provides clues to the mechanism of gene silencing in fragile X syndrome. Hum. Mol. Genet. 19, 4634-4642. doi: 10.1093/hmg/ddq394

Kunst, C. B., Leeflang, E. P., Iber, J. C., Arnheim, N., and Warren, S. T. (1997). The effect of FMR1 CGG repeat interruptions on mutation frequency as measured by sperm typing. J. Med. Genet. 34, 627-631. doi: 10.1136/jmg.34.8.627

Ladd, P. D., Smith, L. E., Rabaia, N. A., Moore, J. M., Georges, S. A., Hansen, R. S., et al. (2007). An antisense transcript spanning the CGG repeat region of FMR1 is upregulated in premutation carriers but silenced in full mutation individuals. J. Neurosci. Res. 16, 3174-3187. 
Lang, W. H., Coats, J. E., Majka, J., Hura, G. L., Lin, Y., Rasnik, I., et al. (2011). Conformational trapping of mismatch recognition complex $\mathrm{MSH} 2 / \mathrm{MSH} 3$ on repair-resistant DNA loops. Proc. Natl. Acad. Sci. U.S.A. 108, E837-E844. doi: 10.1073/pnas.1105461108

Lanni, S., Goracci, M., Borrelli, L., Mancano, G., Chiurazzi, P., Moscato, U., et al (2013). Role of CTCF protein in regulating FMR1 locus transcription. PLoS Genet. 9:e1003601. doi: 10.1371/journal.pgen.1003601

Lavedan, C., Grabczyk, E., Usdin, K., and Nussbaum, R. L. (1998). Long uninterrupted CGG repeats within the first exon of the human FMR1 gene are not intrinsically unstable in transgenic mice. Genomics 50, 229-240. doi: 10.1006/geno.1998.5299

Leehey, M. A., Berry-Kravis, E., Goetz, C. G., Zhang, L., Hall, D. A., Li, L., et al. (2008). FMR1 CGG repeat length predicts motor dysfunction in premutation carriers. Neurology 70, 1397-1402. doi: 10.1212/01.wnl.0000281692. 98200.f5

Lia, A. S., Seznec, H., Hofmann-Radvanyi, H., Radvanyi, F., Duros, C., Saquet, C., et al. (1998). Somatic instability of the CTG repeat in mice transgenic for the myotonic dystrophy region is age dependent but not correlated to the relative intertissue transcription levels and proliferative capacities. Hum. Mol. Genet. 7 , 1285-1291. doi: 10.1093/hmg/7.8.1285

Liu, Y., Winarni, T. I., Zhang, L., Tassone, F., and Hagerman, R. J. (2013). Fragile $\mathrm{X}$-associated tremor/ataxia syndrome (FXTAS) in grey zone carriers. Clin. Genet. 84, 74-77. doi: 10.1111/cge.12026

Loesch, D. Z., Bui, Q. M., Huggins, R. M., Mitchell, R. J., Hagerman, R. J., and Tassone, F. (2007). Transcript levels of the intermediate size or grey zone fragile $\mathrm{X}$ mental retardation 1 alleles are raised, and correlate with the number of CGG repeats. J. Med. Genet. 44, 200-204. doi: 10.1136/jmg.2006.043950

Loesch, D. Z., Godler, D. E., Khaniani, M., Gould, E., Gehling, F., Dissanayake, C., et al. (2009). Linking the FMR1 alleles with small CGG expansions with neurodevelopmental disorders: preliminary data suggest an involvement of epigenetic mechanisms. Am. J. Med. Genet. A 149A, 2306-2310. doi: 10.1002/ajmg.a. 32990

Loesch, D. Z., Huggins, R. M., and Hagerman, R. J. (2004). Phenotypic variation and FMRP levels in fragile X. Ment. Retard. Dev. Disabil. Res. Rev. 10, 31-41. doi: $10.1002 / \mathrm{mrdd} .20006$

Loesch, D. Z., Petrovic, V., Francis, D. I., Oertel, R., and Slater, H. (1997). “Reduction” of CGG trinucleotide expansion from mother to offspring in seven fragile-X families. Clin. Genet. 51, 1-6. doi: 10.1111/j.1399-0004.1997.tb02405.x

Loesch, D. Z., Sherwell, S., Kinsella, G., Tassone, F., Taylor, A., Amor, D., et al. (2012). Fragile $\mathrm{X}$-associated tremor/ataxia phenotype in a male carrier of unmethylated full mutation in the FMR1 gene. Clin. Genet. 82, 88-92. doi: 10.1111/j.13990004.2011.01675.x

Lokanga, A. R., Zhao, X.-N., and Usdin, K. (2014a). X inactivation plays a major role in the gender bias in somatic expansion in a mouse model of the Fragile X-related disorders: implications for the mechanism of repeat expansion. Hum. Mol. Genet. doi: 10.1093/hmg/ddu213 [Epub ahead of print].

Lokanga, R. A., Zhao, X.-N., and Usdin, K. (2014b). The mismatch repair protein, $\mathrm{MSH} 2$, is rate-limiting for repeat expansion in a fragile $\mathrm{X}$ premutation mouse model. Hum. Mutat. 35, 129-136. doi: 10.1002/humu.22464

Lokanga, R. A., Entezam, A., Kumari, D., Yudkin, D., Qin, M., Smith, C. B., et al. (2013). Somatic expansion in mouse and human carriers of fragile X premutation alleles. Hum. Mutat. 34, 157-166. doi: 10.1002/humu.22177

Loomis, E. W., Sanz, L. A., Chedin, F., and Hagerman, P. J. (2014). Transcriptionassociated R-loop formation across the human FMR1 CGG-repeat region. PLoS Genet. 10:e1004294. doi: 10.1371/journal.pgen.1004294

Lugenbeel, K. A., Peier, A. M., Carson, N. L., Chudley, A. E., and Nelson, D. L. (1995). Intragenic loss of function mutations demonstrate the primary role of FMR1 in fragile X syndrome. Nat. Genet. 10, 483-485. doi: 10.1038/ ng0895-483

Lukusa, T., and Fryns, J. P. (2008). Human chromosome fragility. Biochim. Biophys. Acta 1779, 3-16. doi: 10.1016/j.bbagrm.2007.10.005

Maddalena, A., Yadvish, K. N., Spence, W. C., and Howard-Peebles, P. N. (1996). A fragile $\mathrm{X}$ mosaic male with a cryptic full mutation detected in epithelium but not in blood. Am. J. Med. Genet. 64, 309-312. doi: 10.1002/(SICI)10968628(19960809)64:2<309::AID-AJMG15>3.0.CO;2-J

Malter, H. E., Iber, J. C., Willemsen, R., De Graaff, E., Tarleton, J. C., Leisti, J., et al (1997). Characterization of the full fragile X syndrome mutation in fetal gametes. Nat. Genet. 15, 165-169. doi: 10.1038/ng0297-165
Malzac, P., Biancalana, V., Voelckel, M. A., Moncla, A., Pellissier, M. C., Boccaccio, I., et al. (1996). Unexpected inheritance of the (CGG)n trinucleotide expansion in a fragile X syndrome family. Eur. J. Hum. Genet. 4, 8-12.

Manley, K., Shirley, T. L., Flaherty, L., and Messer, A. (1999). Msh2 deficiency prevents in vivo somatic instability of the CAG repeat in Huntington disease transgenic mice. Nat. Genet. 23, 471-473. doi: 10.1038/70598

McConkie-Rosell, A., Lachiewicz, A. M., Spiridigliozzi, G. A., Tarleton, J., Schoenwald, S., Phelan, M. C., et al. (1993). Evidence that methylation of the FMR-I locus is responsible for variable phenotypic expression of the fragile $\mathrm{X}$ syndrome. Am. J. Hum. Genet. 53, 800-809.

McLennan, Y., Polussa, J., Tassone, F., and Hagerman, R. (2011). Fragile x syndrome. Curr. Genomics 12, 216-224. doi: 10.2174/138920211795677886

Mendenhall, E. M., Koche, R. P., Truong, T., Zhou, V. W., Issac, B., Chi, A. S., et al. (2010). GC-rich sequence elements recruit PRC2 in mammalian ES cells. PLoS Genet. 6:e1001244. doi: 10.1371/journal.pgen.1001244

Menoni, H., Hoeijmakers, J. H., and Vermeulen, W. (2012). Nucleotide excision repair-initiating proteins bind to oxidative DNA lesions in vivo. J. Cell Biol. 199, 1037-1046. doi: 10.1083/jcb.201205149

Mila, M., Castellvi-Bel, S., Sanchez, A., Lazaro, C., Villa, M., and Estivill, X. (1996). Mosaicism for the fragile $\mathrm{X}$ syndrome full mutation and deletions within the CGG repeat of the FMR1 gene. J. Med. Genet. 33, 338-340. doi: 10.1136/jmg.33. 4.338

Mirkin, S. M. (2007). Expandable DNA repeats and human disease. Nature 447, 932-940. doi: 10.1038/nature05977

Mirkin, S. M., and Smirnova, E. V. (2002). Positioned to expand. Nat. Genet. 31, 5-6. doi: 10.1038/ng0502-5

Mitas, M., Yu, A., Dill, J., and Haworth, I. S. (1995). The trinucleotide repeat sequence $\mathrm{d}(\mathrm{CGG})_{15}$ forms a heat-stable hairpin containing Gsyn. Ganti base pairs. Biochemistry 34, 12803-12811. doi: 10.1021/bi00039a041

Mollersen, L., Rowe, A. D., Illuzzi, J. L., Hildrestrand, G. A., Gerhold, K. J., Tveteras, L., et al. (2012). Neill is a genetic modifier of somatic and germline CAG trinucleotide repeat instability in R6/1 mice. Hum. Mol. Genet. 21, 4939-4947. doi: $10.1093 / \mathrm{hmg} / \mathrm{dds} 337$

Mornet, E., Chateau, C., Taillandier, A., Simon-Bouy, B., and Serre, J. L. (1996). Recurrent and unexpected segregation of the FMR1 CGG repeat in a family with fragile X syndrome. Hum. Genet. 97, 512-515. doi: 10.1007/BF022 67077

Moutou, C., Vincent, M. C., Biancalana, V., and Mandel, J. L. (1997). Transition from premutation to full mutation in fragile X syndrome is likely to be prezygotic. Hum. Mol. Genet. 6, 971-979. doi: 10.1093/hmg/6.7.971

Muftuoglu, M., De Souza-Pinto, N. C., Dogan, A., Aamann, M., Stevnsner, T., Rybanska, I., et al. (2009). Cockayne syndrome group B protein stimulates repair of formamidopyrimidines by NEIL1 DNA glycosylase. J. Biol. Chem. 284, 92709279. doi: 10.1074/jbc.M807006200

Murray, A., Ennis, S., and Morton, N. (2000). No evidence for parent of origin influencing premature ovarian failure in fragile $\mathrm{X}$ premutation carriers. Am. J. Hum. Genet. 67, 253-254; author reply 256-258. doi: 10.1086/ 302963

Murray, A., Schoemaker, M. J., Bennett, C. E., Ennis, S., Macpherson, J. N., Jones, M., et al. (2014). Population-based estimates of the prevalence of FMR1 expansion mutations in women with early menopause and primary ovarian insufficiency. Genet. Med. 16, 19-24. doi: 10.1038/gim.2013.64

Myrick, L. K., Nakamoto-Kinoshita, M., Lindor, N. M., Kirmani, S., Cheng, X., and Warren, S. T. (2014). Fragile X syndrome due to a missense mutation. Eur. J. Hum. Genet. doi: 10.1038/ejhg.2013.311 [Epub ahead of print].

Nadel, Y., Weisman-Shomer, P., and Fry, M. (1995). The fragile X syndrome single strand $\mathrm{d}(\mathrm{CGG})_{n}$ nucleotide repeats readily fold back to form unimolecular hairpin structures. J. Biol. Chem. 270, 28970-28977. doi: 10.1074/jbc.270.48. 28970

Nakayama, J., Rice, J. C., Strahl, B. D., Allis, C. D., and Grewal, S. I. (2001). Role of histone $\mathrm{H} 3$ lysine 9 methylation in epigenetic control of heterochromatin assembly. Science 292, 110-113. doi: 10.1126/science.1060118

Nolin, S. L., Dobkin, C., and Brown, W. T. (2003). Molecular analysis of fragile X syndrome. Curr. Protoc. Hum. Genet. Chap. 9, Unit 9.5. doi: 10.1002/0471142905.hg0905s38

Nolin, S. L., Glicksman, A., Ding, X., Ersalesi, N., Brown, W. T., Sherman, S. L., et al. (2011). Fragile X analysis of 1112 prenatal samples from 1991 to 2010. Prenat. Diagn. 31, 925-931. doi: 10.1002/pd.2815 
Nolin, S. L., Glicksman, A., Houck, G. E. Jr., Brown, W. T., and Dobkin, C. S. (1994). Mosaicism in fragile X affected males. Am. J. Med. Genet. 51, 509-512. doi: 10.1002/ajmg.1320510444

Nolin, S. L., Lewis, F. A. III, Ye, L. L., Houck, G. E. Jr., Glicksman, A. E., Limprasert, P., et al. (1996). Familial transmission of the FMR1 CGG repeat. Am. J. Hum. Genet. 59, 1252-1261.

Nolin, S. L., Sah, S., Glicksman, A., Sherman, S. L., Allen, E., Berry-Kravis, E., et al. (2013). Fragile X AGG analysis provides new risk predictions for 45-69 repeat alleles. Am. J. Med. Genet. A 161A, 771-778. doi: 10.1002/ajmg.a.35833

Nowicki, S. T., Tassone, F., Ono, M. Y., Ferranti, J., Croquette, M. F., Goodlin-Jones, B., et al. (2007). The Prader-Willi phenotype of fragile X syndrome. J. Dev. Behav. Pediatr. 28, 133-138. doi: 10.1097/01.DBP.0000267563.18952.c9

Owen, B. A., Yang, Z., Lai, M., Gajek, M., Badger, J. D. III, Hayes, J. J., et al. (2005). $(\mathrm{CAG})_{n}$-hairpin DNA binds to Msh2-Msh3 and changes properties of mismatch recognition. Nat. Struct. Mol. Biol. 12, 663-670. doi: 10.1038/nsmb965

Pastore, L. M., Young, S. L., Baker, V. L., Karns, L. B., Williams, C. D., and Silverman, L. M. (2012). Elevated prevalence of 35-44 FMR1 trinucleotide repeats in women with diminished ovarian reserve. Reprod. Sci. 19, 1226-1231. doi: $10.1177 / 1933719112446074$

Pastori, C., Peschansky, V. J., Barbouth, D., Mehta, A., Silva, J. P., and Wahlestedt, C. (2014). Comprehensive analysis of the transcriptional landscape of the human FMR1 gene reveals two new long noncoding RNAs differentially expressed in Fragile X syndrome and Fragile X-associated tremor/ataxia syndrome. Hum. Genet. 133, 59-67. doi: 10.1007/s00439-013-1356-6

Pearson, C. E., Nichol Edamura, K., and Cleary, J. D. (2005). Repeat instability: mechanisms of dynamic mutations. Nat. Rev. Genet. 6, 729-742. doi $10.1038 / \operatorname{nrg} 1689$

Peier, A. M., and Nelson, D. L. (2002). Instability of a premutation-sized CGG repeat in FMR1 YAC transgenic mice. Genomics 80, 423-432. doi: 10.1006/geno.2002.6849

Pelotti, S., Bini, C., Ceccardi, S., Ferri, G., Abbondanza, A., Greggio, N. A., et al. (2003). Sex chromosome analysis in Turner syndrome by a pentaplex PCR assay. Genet. Test. 7, 245-247. doi: 10.1089/109065703322537278

Petek, E., Kroisel, P. M., Schuster, M., Zierler, H., and Wagner, K. (1999). Mosaicism in a fragile X male including a de novo deletion in the FMR1 gene. Am. J. Med Genet. 84, 229-232. doi: 10.1002/(SICI)1096-8628(19990528)84:3<229::AIDAJMG13>3.0.CO;2-T

Pieretti, M., Zhang, F. P., Fu, Y. H., Warren, S. T., Oostra, B. A., Caskey, C. T., et al. (1991). Absence of expression of the FMR-1 gene in fragile X syndrome. Cell 66, 817-822. doi: 10.1016/0092-8674(91)90125-I

Pietrobono, R., Pomponi, M. G., Tabolacci, E., Oostra, B., Chiurazzi, P., and Neri, G. (2002). Quantitative analysis of DNA demethylation and transcriptional reactivation of the FMR1 gene in fragile X cells treated with 5-azadeoxycytidine. Nucleic Acids Res. 30, 3278-3285. doi: 10.1093/nar/gkf434

Pietrobono, R., Tabolacci, E., Zalfa, F., Zito, I., Terracciano, A., Moscato, U., et al. (2005). Molecular dissection of the events leading to inactivation of the FMR gene. Hum. Mol. Genet. 14, 267-277. doi: 10.1093/hmg/ddi024

Powell, W. T., Coulson, R. L., Gonzales, M. L., Crary, F. K., Wong, S. S., Adams, S., et al. (2013). R-loop formation at Snord116 mediates topotecan inhibition of Ube3a-antisense and allele-specific chromatin decondensation. Proc. Natl. Acad. Sci. U.S.A. 110, 13938-13943. doi: 10.1073/pnas.1305426110

Pretto, D. I., Hunsaker, M. R., Cunningham, C. L., Greco, C. M., Hagerman, R. J., Noctor, S. C., et al. (2013). Intranuclear inclusions in a fragile X mosaic male. Transl. Neurodegener. 2, 10. doi: 10.1186/2047-9158-2-10

Pretto, D. I., Mendoza-Morales, G., Lo, J., Cao, R., Hadd, A., Latham, G. J., et al. (2014). CGG allele size somatic mosaicism and methylation in FMR1 premutation alleles. J. Med. Genet. 51, 309-318. doi: 10.1136/jmedgenet-2013102021

Prior, T. W., Papp, A. C., Snyder, P. J., Sedra, M. S., Guida, M., and Enrile, B. G. (1995). Germline mosaicism at the fragile X locus. Am. J. Med. Genet. 55, 384-386. doi: 10.1002/ajmg.1320550327

Renciuk, D., Zemanek, M., Kejnovska, I., and Vorlickova, M. (2009). Quadruplexforming properties of FRAXA (CGG) repeats interrupted by (AGG) triplets. Biochimie 91, 416-422. doi: 10.1016/j.biochi.2008.10.012

Reyniers, E., Martin, J. J., Cras, P., Van Marck, E., Handig, I., Jorens, H. Z., et al. (1999). Postmortem examination of two fragile X brothers with an FMR1 full mutation. Am. J. Med. Genet. 84, 245-249. doi: 10.1002/(SICI)10968628(19990528)84:3<245::AID-AJMG16>3.0.CO;2-U
Reyniers, E., Vits, L., De Boulle, K., Van Roy, B., Van Velzen, D., De Graaff, E., et al. (1993). The full mutation in the FMR-1 gene of male fragile X patients is absent in their sperm. Nat. Genet. 4, 143-146. doi: 10.1038/ng0693-143

Rodriguez-Revenga, L., Madrigal, I., Pagonabarraga, J., Xuncla, M., Badenas, C., Kulisevsky, J., et al. (2009). Penetrance of FMR1 premutation associated pathologies in fragile X syndrome families. Eur. J. Hum. Genet. 17, 1359-1362. doi: 10.1038/ejhg.2009.51

Rohr, J., Allen, E. G., Charen, K., Giles, J., He, W., Dominguez, C., et al. (2008). AntiMullerian hormone indicates early ovarian decline in fragile $\mathrm{X}$ mental retardation (FMR1) premutation carriers: a preliminary study. Hum. Reprod. 23, 1220-1225. doi: 10.1093/humrep/den050

Rougemaille, M., Braun, S., Coyle, S., Dumesic, P. A., Garcia, J. F., Isaac, R. S., et al. (2012). Ers1 links HP1 to RNAi. Proc. Natl. Acad. Sci. U.S.A. 109, 11258-11263. doi: 10.1073/pnas. 1204947109

Rousseau, F., Heitz, D., Biancalana, V., Blumenfeld, S., Kretz, C., Boue, J., etal. (1991). Direct diagnosis by DNA analysis of the fragile X syndrome of mental retardation. N. Engl. J. Med. 325, 1673-1681. doi: 10.1056/NEJM199112123252401

Rousseau, F., Robb, L. J., Rouillard, P., and Der Kaloustian, V. M. (1994). No mental retardation in a man with $40 \%$ abnormal methylation at the FMR-1 locus and transmission of sperm cell mutations as permutations. Hum. Mol. Genet. 3, 927-930. doi: 10.1093/hmg/3.6.927

Santa Maria, L., Pugin, A., Alliende, M., Aliaga, S., Curotto, B., Aravena, T., et al. (2013). FXTAS in an unmethylated mosaic male with fragile X syndrome from Chile. Clin. Genet. doi: 10.1111/cge.12278 [Epub ahead of print].

Santos, F., Hendrich, B., Reik, W., and Dean, W. (2002). Dynamic reprogramming of DNA methylation in the early mouse embryo. Dev. Biol. 241, 172-182. doi: 10.1006/dbio.2001.0501

Savouret, C., Brisson, E., Essers, J., Kanaar, R., Pastink, A., Te Riele, H., et al. (2003). CTG repeat instability and size variation timing in DNA repair-deficient mice. EMBO J. 22, 2264-2273. doi: 10.1093/emboj/cdg202

Schmucker, B., and Seidel, J. (1999). Mosaicism for a full mutation and a normal size allele in two fragile X males. Am. J. Med. Genet. 84, 221-225. doi: 10.1002/(SICI)1096-8628(19990528)84:3<221::AID-AJMG11>3.0.CO;2-M

Sellier, C., Freyermuth, F., Tabet, R., Tran, T., He, F., Ruffenach, F., et al. (2013). Sequestration of DROSHA and DGCR8 by expanded CGG RNA repeats alters microRNA processing in fragile $\mathrm{X}$-associated tremor/ataxia syndrome. Cell Rep. 3, 869-880. doi: 10.1016/j.celrep.2013.02.004

Sellier, C., Rau, F., Liu, Y., Tassone, F., Hukema, R. K., Gattoni, R., et al. (2010). Sam68 sequestration and partial loss of function are associated with splicing alterations in FXTAS patients. EMBO J. 29, 1248-1261. doi: 10.1038/emboj.2010.21

Seritan, A. L., Nguyen, D. V., Farias, S. T., Hinton, L., Grigsby, J., Bourgeois, J. A., et al. (2008). Dementia in fragile X-associated tremor/ataxia syndrome (FXTAS): comparison with Alzheimer's disease. Am. J. Med. Genet. B Neuropsychiatr. Genet. 147B, 1138-1144. doi: 10.1002/ajmg.b.30732

Shapiro, L. R., Simensen, R. J., Wilmot, P. L., Fisch, G. S., Vibert, B. K., Fenwick, R. G., et al. (1994). Asymmetry of methylation with FMR-1 full mutation in two 45,X/46,XX mosaic females associated with normal intellect. Am. J. Med. Genet. 51, 507-508. doi: 10.1002/ajmg.1320510443

Sherman, S. L. (2000). Premature ovarian failure in the fragile X syndrome. Am. J. Med. Genet. 97, 189-194. doi: 10.1002/1096-8628(200023)97:3<189::AIDAJMG1036>3.0.CO;2-J

Smith, S. S., Laayoun, A., Lingeman, R. G., Baker, D. J., and Riley, J. (1994). Hypermethylation of telomere-like foldbacks at codon 12 of the human c-Ha-ras gene and the trinucleotide repeat of the FMR-1 gene of fragile X. J. Mol. Biol. 243, 143-151. doi: 10.1006/jmbi.1994.1640

Spiro, C., Pelletier, R., Rolfsmeier, M. L., Dixon, M. J., Lahue, R. S., Gupta, G., et al. (1999). Inhibition of FEN-1 processing by DNA secondary structure at trinucleotide repeats. Mol. Cell 4, 1079-1085. doi: 10.1016/S1097-2765(00)80236-1

Streuli, I., Fraisse, T., Ibecheole, V., Moix, I., Morris, M. A., and De Ziegler, D. (2009). Intermediate and premutation FMR1 alleles in women with occult primary ovarian insufficiency. Fertil. Steril. 92, 464-470. doi: 10.1016/j.fertnstert.2008.07.007

Sullivan, A. K., Marcus, M., Epstein, M. P., Allen, E. G., Anido, A. E., Paquin, J. J., et al. (2005). Association of FMR1 repeat size with ovarian dysfunction. Hum. Reprod. 20, 402-412. doi: 10.1093/humrep/deh635

Sullivan, S. D., Welt, C., and Sherman, S. (2011). FMR1 and the continuum of primary ovarian insufficiency. Semin. Reprod. Med. 29, 299-307. doi: 10.1055/s0031-1280915 
Sun, Q., Csorba, T., Skourti-Stathaki, K., Proudfoot, N. J., and Dean, C. (2013). Rloop stabilization represses antisense transcription at the Arabidopsis FLC locus. Science 340, 619-621. doi: 10.1126/science.1234848

Sutcliffe, J. S., Nelson, D. L., Zhang, F., Pieretti, M., Caskey, C. T., Saxe, D., et al. (1992). DNA methylation represses FMR-1 transcription in fragile X syndrome. Hum. Mol. Genet. 1, 397-400. doi: 10.1093/hmg/1.6.397

Sutherland, G. R., and Ashforth, P. L. (1979). X-linked mental retardation with macro-orchidism and the fragile site at Xq 27 or 28. Hum. Genet. 48, 117-120. doi: 10.1007/BF00273283

Swift, M., Morrell, D., Cromartie, E., Chamberlin, A. R., Skolnick, M. H., and Bishop, D. T. (1986). The incidence and gene frequency of ataxia-telangiectasia in the United States. Am. J. Hum. Genet. 39, 573-583.

Tabolacci, E., Moscato, U., Zalfa, F., Bagni, C., Chiurazzi, P., and Neri, G. (2008a). Epigenetic analysis reveals a euchromatic configuration in the FMR1 unmethylated full mutations. Eur. J. Hum. Genet. 16, 1487-1498. doi: 10.1038/ejhg.2008.130

Tabolacci, E., Pomponi, M. G., Pietrobono, R., Chiurazzi, P., and Neri, G. (2008b) A unique case of reversion to normal size of a maternal premutation FMR1 allele in a normal boy. Eur. J. Hum. Genet. 16, 209-214. doi: 10.1038/sj.ejhg. 5201949

Tachibana, M., Matsumura, Y., Fukuda, M., Kimura, H., and Shinkai, Y. (2008). G9a/GLP complexes independently mediate H3K9 and DNA methylation to silence transcription. EMBO J. 27, 2681-2690. doi: 10.1038/emboj.2008.192

Tassone, F., Beilina, A., Carosi, C., Albertosi, S., Bagni, C., Li, L., et al. (2007). Elevated FMR1 mRNA in premutation carriers is due to increased transcription. RNA 13, 555-562. doi: 10.1261/rna.280807

Tassone, F., and Hagerman, R. (2012). The fragile X-associated tremor ataxia syndrome. Results Probl. Cell Differ. 54, 337-357. doi: 10.1007/978-3-642-216497_18

Tassone, F., Hagerman, R. J., Chamberlain, W. D., and Hagerman, P. J. (2000a). Transcription of the FMR1 gene in individuals with fragile $\mathrm{X}$ syndrome. Am. J. Med. Genet. 97, 195-203. doi: 10.1002/1096-8628(200023)97:3<195::AIDAJMG1037>3.0.CO;2-R

Tassone, F., Hagerman, R. J., Loesch, D. Z., Lachiewicz, A., Taylor, A. K., and Hagerman, P. J. (2000b). Fragile X males with unmethylated, full mutation trinucleotide repeat expansions have elevated levels of FMR1 messenger RNA. Am J. Med. Genet. 94, 232-236. doi: 10.1002/1096-8628(20000918)94:3<232::AIDAJMG9>3.0.CO;2-H

Tassone, F., Hagerman, R. J., Taylor, A. K., Gane, L. W., Godfrey, T. E., and Hagerman, P. J. (2000c). Elevated levels of FMR1 mRNA in carrier males: a new mechanism of involvement in the fragile-X syndrome. Am. J. Hum. Genet. 66, 6-15. doi: $10.1086 / 302720$

Tassone, F., Hagerman, R. J., Ikle, D. N., Dyer, P. N., Lampe, M., Willemsen, R., et al. (1999). FMRP expression as a potential prognostic indicator in fragile X syndrome. Am. J. Med. Genet. 84, 250-261. doi: 10.1002/(SICI)10968628(19990528)84:3<250::AID-AJMG17>3.0.CO;2-4

Tassone, F., Iwahashi, C., and Hagerman, P. J. (2004). FMR1 RNA within the intranuclear inclusions of fragile X-associated tremor/ataxia syndrome (FXTAS). RNA Biol. 1, 103-105. doi: 10.4161/rna.1.2.1035

Taylor, A. K., Tassone, F., Dyer, P. N., Hersch, S. M., Harris, J. B., Greenough, W. T., et al. (1999). Tissue heterogeneity of the FMR1 mutation in a high-functioning male with fragile X syndrome. Am. J. Med. Genet. 84, 233 239. doi: 10.1002/(SICI)1096-8628(19990528)84:3<233::AID-AJMG14>3.0. $\mathrm{CO} ; 2-6$

Tejada, M. I., Garcia-Alegria, E., Bilbao, A., Martinez-Bouzas, C., Beristain, E., Poch, M., et al. (2008). Analysis of the molecular parameters that could predict the risk of manifesting premature ovarian failure in female premutation carriers of fragile X syndrome. Menopause 15, 945-949. doi: 10.1097/gme.0b013e31816 47762

Tejada, M. I., Mornet, E., Tizzano, E., Molina, M., Baiget, M., and Boue, A. (1994). Identification by molecular diagnosis of mosaic Turner's syndrome in an obligate carrier female for fragile X syndrome. J. Med. Genet. 31, 76-78. doi: 10.1136/jmg.31.1.76

Todd, P. K., Oh, S. Y., Krans, A., He, F., Sellier, C., Frazer, M., et al. (2013). CGG repeat-associated translation mediates neurodegeneration in fragile $\mathrm{X}$ tremor ataxia syndrome. Neuron 78, 440-455. doi: 10.1016/j.neuron.2013.03.026

Todd, P. K., Oh, S. Y., Krans, A., Pandey, U. B., Di Prospero, N. A., Min, K. T., et al. (2010). Histone deacetylases suppress CGG repeat-induced neurodegeneration via transcriptional silencing in models of fragile $\mathrm{X}$ tremor ataxia syndrome. PLoS Genet. 6:e1001240. doi: 10.1371/journal.pgen.1001240

Todorov, T., Todorova, A., Kirov, A., Dimitrov, B., Carvalho, R., Nygren, A. O., et al. (2009). Fragile X mosaic male full mutation/normal allele detected by PCR/MSMLPA. BMJ Case Rep. 2009, bcr06.2008.0139. doi: 10.1136/bcr.06.2008.0139

Tome, S., Manley, K., Simard, J. P., Clark, G. W., Slean, M. M., Swami, M., et al. (2013). MSH3 polymorphisms and protein levels affect CAG repeat instability in Huntington's disease mice. PLoS Genet. 9:e1003280. doi: 10.1371/journal.pgen. 1003280

Trost, N., Cook, M., Hammersley, E., Bui, M. Q., Brotchie, P., Burgess, T., et al. (2013). White matter changes in patients with Parkinson's disease carrying small CGG expansion FMR1 alleles: a pilot study. Neurodegener. Dis. doi: 10.1159/000356190 [Epub ahead of print].

Turner, G., Daniel, A., and Frost, M. (1980). X-linked mental retardation, macroorchidism, and the Xq27 fragile site. J. Pediatr. 96, 837-841. doi: 10.1016/S00223476(80)80552-X

Usdin, K. (1998). NGG-triplet repeats form similar intrastrand structures: implications for the triplet expansion diseases. Nucleic Acids Res. 26, 4078-4085. doi: $10.1093 / \mathrm{nar} / 26.17 .4078$

Usdin, K. (2008). The biological effects of simple tandem repeats: lessons from the repeat expansion diseases. Genome Res. 18, 1011-1019. doi: 10.1101/gr.070409.107

Usdin, K., and Woodford, K. J. (1995). CGG repeats associated with DNA instability and chromosome fragility form structures that block DNA synthesis in vitro. Nucleic Acids Res. 23, 4202-4209. doi: 10.1093/nar/23.20.4202

Vaisanen, M. L., Haataja, R., and Leisti, J. (1996). Decrease in the CGGn trinucleotide repeat mutation of the fragile $\mathrm{X}$ syndrome to normal size range during paternal transmission. Am. J. Hum. Genet. 59, 540-546.

van den Broek, W. J., Nelen, M. R., Wansink, D. G., Coerwinkel, M. M., Te Riele, H., Groenen, P. J., et al. (2002). Somatic expansion behaviour of the $(\mathrm{CTG})_{n}$ repeat in myotonic dystrophy knock-in mice is differentially affected by Msh3 and Msh6 mismatch-repair proteins. Hum. Mol. Genet. 11, 191-198. doi: 10.1093/hmg/11.2.191

Verkerk, A. J., Pieretti, M., Sutcliffe, J. S., Fu, Y. H., Kuhl, D. P., Pizzuti, A., et al. (1991). Identification of a gene (FMR-1) containing a CGG repeat coincident with a breakpoint cluster region exhibiting length variation in fragile $\mathrm{X}$ syndrome. Cell 65, 905-914. doi: 10.1016/0092-8674(91)90397-H

Vire, E., Brenner, C., Deplus, R., Blanchon, L., Fraga, M., Didelot, C., et al. (2006). The Polycomb group protein EZH2 directly controls DNA methylation. Nature 439, 871-874. doi: 10.1038/nature04431

Voineagu, I., Surka, C. F., Shishkin, A. A., Krasilnikova, M. M., and Mirkin, S. M. (2009). Replisome stalling and stabilization at CGG repeats, which are responsible for chromosomal fragility. Nat. Struct. Mol. Biol. 16, 226-228. doi: 10.1038/nsmb. 1527

Volpe, T. A., Kidner, C., Hall, I. M., Teng, G., Grewal, S. I., and Martienssen, R. A. (2002). Regulation of heterochromatic silencing and histone H3 lysine-9 methylation by RNAi. Science 297, 1833-1837. doi: 10.1126/science. 1074973

Voorhuis, M., Onland-Moret, N. C., Fauser, B. C., Ploos Van Amstel, H. K., Van Der Schouw, Y. T., and Broekmans, F. J. (2013). The association of CGG repeats in the FMR1 gene and timing of natural menopause. Hum. Reprod. 28, 496-501. doi: 10.1093/humrep/des392

Wang, L. W., Berry-Kravis, E., and Hagerman, R. J. (2010). Fragile X: leading the way for targeted treatments in autism. Neurotherapeutics 7, 264-274. doi: 10.1016/j.nurt.2010.05.005

Wang, Y. H., Gellibolian, R., Shimizu, M., Wells, R. D., and Griffith, J. (1996). Long CCG triplet repeat blocks exclude nucleosomes: a possible mechanism for the nature of fragile sites in chromosomes. J. Mol. Biol. 263, 511-516. doi: 10.1006/jmbi.1996.0593

Webb, T. (1992). Delayed replication of Xq27 in individuals with the fragile X syndrome. Am. J. Med. Genet. 43, 1057-1062. doi: 10.1002/ajmg.1320430633

Weisman-Shomer, P., Cohen, E., and Fry, M. (2000). Interruption of the fragile X syndrome expanded sequence $\mathrm{d}(\mathrm{CGG})_{n}$ by interspersed $\mathrm{d}(\mathrm{AGG})$ trinucleotides diminishes the formation and stability of $\mathrm{d}(\mathrm{CGG})_{n}$ tetrahelical structures. Nucleic Acids Res. 28, 1535-1541. doi: 10.1093/nar/28.7.1535

Welt, C. K., Smith, P. C., and Taylor, A. E. (2004). Evidence of early ovarian aging in fragile X premutation carriers. J. Clin. Endocrinol. Metab. 89, 4569-4574. doi: 10.1210/jc.2004-0347 
Wilkin, H., Tuohy, J., and Theewis, W. (2000). Prenatal diagnosis of fragile X and Turner mosaicism in a 12-week fetus. Prenat. Diagn. 20, 854-855. doi: 10.1002/1097-0223(200010)20:10<854::AID-PD928>3.0.CO;2-1

Willemsen, R., Bontekoe, C. J., Severijnen, L. A., and Oostra, B. A. (2002). Timing of the absence of FMR1 expression in full mutation chorionic villi. Hum. Genet. 110, 601-605. doi: 10.1007/s00439-002-0723-5

Wittenberger, M. D., Hagerman, R. J., Sherman, S. L., Mcconkie-Rosell, A., Welt, C. K., Rebar, R. W., et al. (2007). The FMR1 premutation and reproduction. Fertil Steril. 87, 456-465. doi: 10.1016/j.fertnstert.2006.09.004

Wohrle, D., Salat, U., Glaser, D., Mucke, J., Meisel-Stosiek, M., Schindler, D., et al. (1998). Unusual mutations in high functioning fragile X males: apparent instability of expanded unmethylated CGG repeats. J. Med. Genet. 35, 103-111. doi: 10.1136/jmg.35.2.103

Wohrle, D., Salat, U., Hameister, H., Vogel, W., and Steinbach, P. (2001). Demethylation, reactivation, and destabilization of human fragile $\mathrm{X}$ full-mutation alleles in mouse embryocarcinoma cells. Am. J. Hum. Genet. 69, 504-515. doi: $10.1086 / 322739$

Yrigollen, C. M., Durbin-Johnson, B., Gane, L., Nelson, D. L., Hagerman, R. Hagerman, P. J., et al. (2012). AGG interruptions within the maternal FMR1 gene reduce the risk of offspring with fragile X syndrome. Genet. Med. 14, 729-736. doi: 10.1038/gim.2012.34

Yu, A., Barron, M. D., Romero, R. M., Christy, M., Gold, B., Dai, J., et al. (1997). At physiological $\mathrm{pH}, \mathrm{d}(\mathrm{CCG})_{15}$ forms a hairpin containing protonated cytosines and a distorted helix. Biochemistry 36, 3687-3699. doi: 10.1021/bi96 25410

Yudkin, D., Hayward, B. E., Aladjem, M. I., Kumari, D., and Usdin, K. (2014). Chromosome fragility and the abnormal replication of the FMR1 locus in
Fragile X syndrome. Hum. Mol. Genet. 23, 2940-2952. doi: 10.1093/hmg/ ddu006

Zhao, X.-N., and Usdin, K. (2014). Gender and cell-type specific effects of the transcription coupled repair protein, ERCC6/CSB, on repeat expansion in a mouse model of the Fragile X-related disorders. Hum. Mutat. 35, 341-349. doi: 10.1002/humu.22495

Zhong, N., Ju, W., Pietrofesa, J., Wang, D., Dobkin, C., and Brown, W. T. (1996). Fragile X "gray zone" alleles: AGG patterns, expansion risks, and associated haplotypes. Am. J. Med. Genet. 64, 261-265. doi: 10.1002/(SICI)10968628(19960809)64:2<261::AID-AJMG5>3.0.CO;2-X

Conflict of Interest Statement: The authors declare that the research was conducted in the absence of any commercial or financial relationships that could be construed as a potential conflict of interest.

Received: 12 May 2014; accepted: 29 June 2014; published online: 17 July 2014.

Citation: Usdin K, Hayward BE, Kumari D, Lokanga RA, Sciascia N and Zhao X-N (2014) Repeat-mediated genetic and epigenetic changes at the FMR1 locus in the Fragile $X$-related disorders. Front. Genet. 5:226. doi: 10.3389/fgene.2014.00226

This article was submitted to Genetic Disorders, a section of the journal Frontiers in Genetics.

Copyright (c) 2014 Usdin, Hayward, Kumari, Lokanga, Sciascia and Zhao. This is an open-access article distributed under the terms of the Creative Commons Attribution License (CC BY). The use, distribution or reproduction in other forums is permitted, provided the original author(s) or licensor are credited and that the original publication in this journal is cited, in accordance with accepted academic practice. No use, distribution or reproduction is permitted which does not comply with these terms. 